\title{
FORMY PROFESJONALIZMU LEKARSKIEGO I ICH PRZYDATNOŚĆ W EDUKACJI MORALNEJ STUDENTÓW MEDYCYNY I MLODYCH LEKARZY ${ }^{1}$
}

\author{
- Kazimierz Szewczyk -
}

\begin{abstract}
Abstrakt: W pierwszej części artykułu charakteryzuję trzy rodzaje profesjonalizmu lekarskiego: profesjonalizm tradycyjny, odnowiony i kompleksowy. Omawiam także czynniki kulturowe, ekonomiczne i aksjologiczne wpływające na ich kształtowanie się. Stawiam tezę, że profesjonalizm kompleksowy ze względu na jego skomplikowanie i arbitralne wyodrębnianie elementów składowych jest nieprzydatny w edukacji moralnej studentów i lekarzy. W części drugiej rekonstruuję wady i zalety profesjonalizmu tradycyjnego i odnowionego. Uzasadniam pogląd, że najważniejsza zaleta profesjonalizmu wynika z jego ambiwalencji moralnej. Nie traktuję więc tej dwuznaczności jako wyłącznie wady. Lekarz profesjonalista powinien mieć świadomość jasnych i ciemnych stron profesjonalizmu oraz umiejętność właściwego ich ważenia w danych okolicznościach - poszukiwania Arystotelesowskiego złotego środka. W ostatniej części argumentuję za umiarkowanie optymistycznym przekonaniem o przydatności profesjonalizmu tradycyjnego i odnowionego w moralnym formowaniu studentów medycyny i młodych lekarzy.

Słowa kluczowe: tradycyjny profesjonalizm lekarski, odnowiony profesjonalizm lekarski, kompleksowy profesjonalizm lekarski, edukacja moralna, E. Erde, J. Gregory, F. Hafferty, T. Percival, H. Swick. Published online: 28 August 2019
\end{abstract}

W późnych latach 80 . ubiegłego wieku rozpoczął się renesans zainteresowania lekarzy i edukatorów medycznych profesjonalizmem lekarskim przybierając wkrótce formę „ruchu profesjonalnego" ${ }^{2}$. W 2005 roku skokowo wzrosła liczba publikacji edukacyjnych zajmujących się profesjonalizmem³ ${ }^{3}$ Obecnie profesjonalizm „stał się bez wątpienia centralnym pojęciem w literaturze omawiającej etyczną edukację studentów medycyny"4. Fala zainteresowania nim dotarła również do Polski. Niektóre uniwersytety medyczne mają w swojej ofercie dydaktycznej kursy z elementów profesjonalizmu. Tytułem

Kazimierz Szewczyk

Instytut Filozofii UW

ul. Krakowskie Przedmieście 3

00-927 Warszawa

email: kazimierz_szewczyk@onet.eu

${ }^{1}$ Publikacja finansowana w ramach programu Ministra Nauki i Szkolnictwa Wyższego pod nazwą „Narodowy Program Rozwoju Humanistyki" w latach 2016-2019, nr grantu: 2bH 150185 83. Dziękuję anonimowemu Recenzentowi za uwagi i sugestie korygujące niedociągnięcia pierwotnej wersji artykułu.

${ }^{2}$ Kuczewski (2010): 32.

${ }^{3}$ Coulehan (2005): 892.

${ }^{4}$ Giubilini, Milnes, Savulescu (2016): 132. 
przykładu przywołam Uniwersytet Medyczny w Białymstoku ${ }^{1}$ i Wydział Medyczny Uniwersytetu Warmińsko-Mazurskiego ${ }^{2}$. Profesjonalizm lekarski jest także uwzględniony w podręczniku Pawła Łukowa i Tomasza Pasierskiego Etyka medyczna z elementami filozofii ${ }^{3}$. Aktywności dydaktycznej nie towarzyszy jednakże na rynku krajowym bardziej pogłębiona refleksja teoretyczna nad tym ruchem. Do nielicznych wyjątków należy cykl artykułów opublikowanych w latach 2012-2015 w „Medycynie po Dyplomie” i zebranych w książce Profesjonalizm lekarski pod redakcją Janusza Janczukowicza ${ }^{4}$.

Profesjonalizm mimo tak dużego zainteresowania nie doczekał się ogólnie przyjętej definicji. Rezultaty dotychczasowych prób jego definiowania są, jak pisze Edmund Erde, "niedopuszczalnie nieprecyzyjne”, zakresowo zbyt wąskie bądź nadmiernie szerokie ${ }^{5}$. Przywołany autor wyjaśnia brak „jasnej i niedwuznacznej” definicji profesjonalizmu. Powodem jest wielość wątków, które definicja taka musiałaby objąć. Inaczej mówiąc, profesjonalizm jest terminem nadrzędnym (umbrella term) i jako taki nie poddaje się adekwatnej definicji ${ }^{6}$. W tej sytuacji metodologicznej E. Erde postuluje rezygnację z prób definiowania profesjonalizmu lekarskiego. Wysiłki definicyjne ma zastąpić między innymi pokazanie historii profesjonalizmu i postępowania uznawanego za profesjonalne, a także rekonstrukcja opisu wartości i cnót, zachowań i obowiązków wyłonionych w tej historii. Badania historyczne pozwolą na zrozumienie znaczenia liczby składników profesjonalizmu nieosiągalnej w jego definicjach ${ }^{7}$. Akceptując ten postulat, pominę analizę definicji profesjonalizmu lekarskiego obecnych w literaturze przedmiotu i skupię się na ukazaniu historii tego fenomenu. Skoncentrowanie się na diachronicznym wymiarze profesjonalizmu pozwala także na ukazanie w jednym tekście wzajemnych powiązań poszczególnych jego form. Podobnego opracowania nie spotkałem w dostępnej mi bibliografii. Historycznie pierwszą formę nazwałem profesjonalizmem tradycyjnym, aby podkreślić jego prekursorstwo i silny wpływ na tradycję moralną profesji. Kolejne postacie profesjonalizmu - odnowiony i kompleksowy - będą się formowały w jego cieniu, kontynuując pewne elementy tradycji, inne zaś negując. Terminu „profesjonalizm tradycyjny” używam zamiennie z określeniem „profesjonalizm klasyczny". Dokonane rekonstrukcje form profesjonalizmu posłużą mi do krótkiej oceny ich przydatności w edukacji moralnej studentów medycyny i młodych lekarzy.

\section{Profesjonalizm tradycyjny}

\section{1.a. Prehistoria profesjonalizmu tradycyjnego - John Gregory i Thomas Percival}

Właściwy medycynie konflikt między interesem własnym lekarza i dobrem pacjenta praktyka medyczna przed powstaniem medycyny klinicznej rozstrzygnęła całkowicie

\footnotetext{
1 Uniwersytet Medyczny w Białymstoku (2017).

2 Uniwersytet Warmińsko-Mazurski (2017).

3 Łuków, Pasierski (2014): 109-120.

4 Janczukowicz (2014); zob. też: Pasierski (2009); Włodarczyk, Badora-Musiał (2017).

5 Erde (2008): 12.

${ }^{6}$ Ibidem: 7.

7 Ibidem: 8 .
} 
na rzecz interesu lekarza ${ }^{8}$. W osiemnastowiecznej Brytanii i jej koloniach w Północnej Ameryce działalność lekarzy była przez nich bez reszty traktowana jak przedsięwzięcie biznesowe nastawione na zysk. Model praktyki lekarskiej stanowiła praca indywidualna medyka o charakterze kontraktu biznesowego między nim i chorym. Chory płacił i wymagał od lekarza świadczenia danej usługi. Lekarz nie miał zatem praktycznie żadnej władzy nad swoim klientem. Stowarzyszenia lekarskie były w istocie merkantylnymi gildiami zabiegającymi przede wszystkim o interesy swoich członków. Terminu „profesja" lekarze używali dla odróżnienia siebie od współzawodniczących z nimi chirurgów, dentystów i aptekarzy, a także wszelkiego autoramentu szarlatanów i znachorów ${ }^{9}$.

Zakładane w okresie rewolucji przemysłowej infirmerie ujawniły z całą wyrazistością niedostatki dotychczasowego modelu relacji lekarza z jego bogatym chorym-klientem. Podopiecznymi tych instytucji byli ludzie ubodzy, co sprawiło, że zatrudnieni w nich lekarze zyskali po raz pierwszy władzę nad chorymi. Skutkowało to wieloma negatywnymi zachowaniami medyków w stosunku do pensjonariuszy lecznic. Wykorzystywano ich w „eksperymentach” nad nowymi sekretnymi lekarstwami na wszystko. Często także porzucano podopiecznych lecznic dla prywatnej praktyki. Zachowania lekarzy infirmerii stały się moralnie kłopotliwe dla części światłych konsyliarzy. Szczególne zasługi w przystosowywaniu praktyki lekarskiej do nowych instytucji opieki zdrowotnej mają dwaj wykształceni filozoficznie lekarze: Szkot John Gregory (1724-1775) i Anglik Thomas Percival (1740-1803). Ich praca - najkrócej rzecz ujmując - polegała na uzasadnieniu podporządkowania interesów lekarzy dobru chorych i na wyciąganiu konsekwencji moralnych i społecznych z tego podporządkowania. W tradycji moralnej medycyny zachodniej była to radykalna zmiana w hierarchii wartości lekarzy. W połączeniu z czynnikami kulturowymi, przede wszystkim z ideami oświecenia, doprowadziła do powstania profesjonalizmu tradycyjnego ${ }^{10}$. Bardzo ważne było także oddziaływanie dzieła Francisa Bacona The Advancement of Learning z 1605 roku. Według Roberta Bakera autor zbudował w nim „projekt nowoczesnej medycyny i jej etyki”. Podstawą pierwszej miała być nauka empiryczna. Natomiast postępowanie lekarzy powinno być regulowane przez normy etyczne wspólnie przez nich opracowywane. Tym samym F. Bacon sformułował postulat profesjonalnej samodyscypliny jako istotnego wyróżnika medycyny nowoczesnej ${ }^{11}$.

Wysunięcie na pierwszy plan powinności zabiegania o dobro chorego pociągało za sobą zakwestionowanie dotychczasowego modelu relacji biznesowej łączącej lekarza $\mathrm{z}$ chorym. Wymagało także skonstruowania moralnych podstaw nowego ujęcia stosunku lekarz - pacjent. Roli budowniczego podjął się J. Gregory. Elementów do konstrukcji dostarczyły mu filozofia D. Hume'a oraz obserwacja sięgających średniowiecza więzi społecznych łączących arystokratów z ubogimi wówczas góralami szkockimi. Był to, jak nazywa go Laurence McCullough, „moralno-arystokratyczny paternalizm” nakazujący pomagać Szkotom znajdującym się niżej w hierarchii społecznej i będącym w potrzebie $^{12}$. Od D. Hume'a zaczerpnął Gregory pojęcie sympatii. Stosunek oparty na sympatii

\footnotetext{
8 Szewczyk (2009): 23.

${ }^{9}$ McCullough (2006): 19.

10 Veatch (2013): 166.

11 Baker (2002): 460.

12 McCullough (1998): 12.
} 
i moralno-arystokratycznym paternalizmie stanowił $\mathrm{w}$ istocie swej relację powierniczą (fiduciary relation $)^{13}$. Lekarzowi został przyznany moralny status powiernika chorego. Ten zaś przestał być klientem, stając się pacjentem ${ }^{14}$. Sympatia i moralno-arystokratyczny paternalizm znalazły odbicie w skonstruowanym przez J. Gregory'ego pierwszym składniku konstytuującym etyczną podstawę medycyny jako profesji i profesjonalizmu tradycyjnego. Jest nim konieczność angażowania się lekarza w ochronę i wspieranie interesów zdrowotnych pacjentów niezależnie od ich statusu materialnego.

J. Gregory'emu bliska była także idea medycyny empirycznej F. Bacona. Ubolewał nad „będącym w zastoju i niebezpiecznie nienaukowym stanem większości osiemnastowiecznej praktyki lekarskiej"15. Pod wpływem tego filozofa i obserwacji kondycji naukowej i klinicznej ówczesnej medycyny omawiany autor sformułował drugi składnik etycznej podstawy profesji medycznej - nieprzerwane nabywanie i rozwijanie przez lekarzy kompetencji naukowych i klinicznych oraz zmierzanie do perfekcji w obu tych obszarach. Perfekcjonizm profesjonalizmu tradycyjnego i podporządkowanie interesu własnego lekarzy dobru pacjenta wymagał od nich kierowania się trzema cnotami: dążeniem do doskonałości w wypełnianiu swoich powinności, empatią oraz samopoświęceniem. Samopoświęcenie wraz z bliskim mu altruizmem stanie się stałym wyróżnikiem charakteru profesjonalisty, „szpikiem jego moralnego kośćca ${ }^{16}$.

Trzeci element profesjonalizmu klasycznego sformułował T. Percival. L. McCullough ujmuje go następująco: medycyna nie jest organizacją merkantylną, lecz stanowi profesję zaufania publicznego ${ }^{17}$. Kenneth Boyd traktuje tę fundamentalną dla historii profesjonalizmu zmianę jako reinterpretację etosu gildii dostosowującą go do potrzeb naukowego i industrialnego społeczeństwa. Było ono nadal hierarchiczne i „nierzadko oparte na szacunku do usytuowanych wyżej w tej hierarchii"18. Autor opisuje T. Percivala jako „osiemnastowiecznego funkcjonariusza medycznego i chrześcijańskiego dżentelmena" ${ }^{\prime 19}$. Kultywowany przez niego etos honoru dżentelmeńskiego legł u podstaw profesjonalizmu zachodniego ${ }^{20}$.

\section{1.b. Profesjonalizm tradycyjny - Kodeks etyki lekarskiej Amerykańskiego Towarzystwa Lekarskiego (AMA) z 1847 roku}

Rewolucyjnym wydarzeniem $\mathrm{w}$ formowaniu się profesjonalizmu tradycyjnego (i tradycyjnej etyki lekarskiej) było zredagowanie i opublikowanie Kodeksu etyki lekarskiej21. Stanowił on pierwszy dokument etyczny opracowany zbiorowym wysiłkiem członków profesji lekarskiej i przez nich zaakceptowany na zjeździe założycielskim AMA w 1847

${ }^{13}$ McCullough (2006): 24.

${ }^{14}$ J. Gregory i T. Percival byli pierwszymi w historii zachodniej medycyny autorami zastępującymi słowo "chory" terminem "pacjent".

${ }^{15}$ Boyd (2005): 481. Ten i kolejne cytaty z opracowań anglojęzycznych w tłumaczeniu własnym.

${ }_{16}$ Beaton (2010): 21.

${ }^{17}$ McCullough (2006): 22.

${ }_{18}$ Boyd (2005): 481.

${ }^{19}$ Ibidem.

${ }^{20}$ Baker (2013): 97.

${ }^{21}$ American Medical Association (1847). 
roku. Społeczno-kulturowe realia działalności redaktorów Kodeksu były diametralnie odmienne od tych, w których tworzyli J. Gregory i T. Percival. R. Veatch nazywa ten okres w historii moralnej medycyny "ciemnymi wiekami etyki lekarskiej” ${ }^{22}$. W czasach J. Gregory'ego i T. Percivala - rozwija swoje stwierdzenie R. Veatch - kandydaci na lekarzy wywodzili się przede wszystkim z elit społecznych i otrzymywali gruntowne wykształcenie klasyczne w domach i szkołach prywatnych. Na początku XIX wieku studenci medycyny pochodzili raczej ze średnich klas. Również sama medycyna stawała się bardziej techniczna i wyspecjalizowana. Nasilała się presja na usuwanie humanistyki z programów studiów na korzyść bardziej przyrodniczej i technicznej edukacji. Równocześnie etos pracy kultywowany przez klasę średnią sprzyjał akcentowaniu cnoty samopoświęcenia. W starszej generacji lekarzy wychowanych w duchu profesjonalizmu klasycznego samopoświęcenie dotyczyło właściwie całości życia prywatnego. Profesor Józef Bogusz (1904-1993), przewodniczący komitetu redakcyjnego przyjętego przez Polskie Towarzystwo Lekarskie w 1977 Zbioru zasad etyczno-deontologicznych polskiego lekarza, często i chętnie wypowiadający się na temat moralności lekarskiej, tak wspomina swój wzór osobowy - profesora Maksymiliana Rutkowskiego (1867-1947): „W stosunku do uczniów swych był surowy i wymagający. Był zawsze taki wobec siebie, całe życie sam był w służbie ludzi chorych, tego też wymagał od swych asystentów. Życie prywatne, własne ja lekarza, nie liczyło się tu prawie zupełnie. Na pierwszym planie był zawsze i wyłącznie chory" 23. Samopoświęcenie przeradza się w pracoholizm.

Brak szerszego kulturowego zaplecza sprawił, że redaktorzy Kodeksu w poszukiwaniu inspiracji sięgnęli do dzieł J. Gregory'ego i przede wszystkim T. Percivala. Zaproponowane przez nich trzy składniki etycznej podstawy medycyny łącznie z przystosowaną do wymogów profesji ideą honoru dżentelmena zostały włączone w Kodeks. Ta ostatnia była wręcz w ten dokument „wbudowana”24. Jako szczególnie wyraźny przykład takiego wbudowania przywołam par. 2. artykułu I. rozdziału II. Stwierdza się w nim, że profesja lekarska jest profesją unikatową, gdyż jako jedyna wymaga do swych członków „najwyższej czystości charakteru i najwyższych standardów moralnej doskonałości”. Dążenie do takiej perfekcji ,jest obowiązkiem każdego lekarza wobec profesji i pacjentów". Co istotne, redaktorzy uzasadniają wagę dążenia do perfekcji moralnej również i tym, że doskonałość kliniczna i osiągnięcia naukowe lekarza nie mogą jej ani równoważyć, ani zastępować. Cytowany przepis pokazuje, że wbudowanie idei T. Percivala łączyło się z przemianą cnót charakteru lekarza w jego profesjonalne obowiązki ${ }^{25}$. Nie była to przemiana w pełni konsekwentna, a poprzedzał ją istotny - choć także niekonsekwentny - zwrot w moralności lekarskiej od etyki charakteru (ethics of charakter) do etyki postępowania (ethics of conduct) ${ }^{26}$.

Rdzeń omawianego dokumentu zawiera przepisy chroniące dobrostan pacjentów oraz regulujące etyczne zachowanie indywidualnych lekarzy $\mathrm{w}$ ich interakcjach $\mathrm{z}$ chorymi. Eliot Freidson normy te nazywa etyką praktykowania (practice ethics). Odróżnia je

\footnotetext{
22 Veatch (2013): 166.

23 Bogusz (1984): 125.

24 Baker, Caplan, Emanuel, Latham (1999): XXXII.

25 Baker (1999): 39.

${ }^{26}$ Ibidem: 36.
} 
od - równie ważnych - przepisów kształtujących społeczne i ekonomiczne okoliczności, w których mają miejsce kliniczne kontakty lekarzy z pacjentami - ich praktyka. Normy te autor określa mianem etyki instytucjonalnej (institutional ethics) ${ }^{27}$. Jest to moim zdaniem trafniejsza nazwa niż częściej używany termin - „normy etykietalne”. Pokazuje bowiem, że ta - rozbudowana w Kodeksie - część unormowań stanowi podwaliny medycyny jako instytucji łącznie z korporacyjną kulturą lekarzy-profesjonalistów.

Etyka praktykowania medycyny jest unormowana w siedmiu paragrafach rozdziału I., art. I zatytułowanego Obowiązki lekarzy wobec pacjentów. Paragraf 1. tego artykułu (w dużej części przejęty in extenso od T. Percivala) stanowi między innymi, że myśl lekarza „powinna być przepojona wielkością jego misji i odpowiedzialności, niezmiennie powiązanej z jej wypełnianiem”, a służąc chorym medycy powinni należycie podkreślać znaczenie ich urzędu. Stąd też lekarze muszą starać się w swoim zachowaniu w taki sposób „połączyć delikatność ze stanowczościq i łaskawość z autorytetem aby natchnąć umysły pacjentów wdzięcznością, szacunkiem i ufnością" (kursywa w oryginale) ${ }^{28}$. W przywołanych sformułowaniach podobnie jak w cytowanym wyżej par. 2. artykułu I. rozdziału II. widać elementy paternalizmu arystokratycznego J. Gregory'ego. Teraz jednak jest on ujmowany z perspektywy kodeksu dżentelmena zaczerpniętej z pism T. Percivala. Pomoc osobom potrzebującym, wynikająca z cechującej dżentelmena czy szkockiego arystokraty cnoty dobroczynienia, staje się obowiązkiem lekarza wobec pacjentów. Jednocześnie kodeks honorowy wymagał odnoszenia się z szacunkiem do osób wyżej postawionych w hierarchii społecznej. Stąd też również pacjentów należy swoim zachowaniem uczyć takiego szacunku. Niewykluczone, że kultywowaniu owego arystokratyzmu moralnego sprzyjała niepewność redaktorów dotycząca statusu społecznego profesji, wciąż jeszcze "problematycznego" 29.

W omawianym paragrafie 1 . Obowiązków lekarzy wobec pacjentów zadekretowane jest też miejsce sumienia lekarza jako jedynego i najwyższego „trybunału w osądzaniu kar za zaniedbanie lub beztroskę". Jest to efekt ewolucji etyki lekarskiej prowadzącej od wierności kościołowi i państwu (koronie) do wierności (i służbie) choremu i jego ciału $^{30}$. Z czasem wolność od uwarunkowań religijnych uzyskała status stałej zasady amerykańskiego profesjonalizmu lekarskiego. „Włączanie przekonań religijnych lub etyki religijnej do procesu decyzyjnego lekarzy było uznawane za 'nieprofesjonalne'"31. Niezależność sumienia lekarza jest tu przejawem jego autonomii profesjonalnej i zarazem stoi na straży niezależności profesji jako całości. Uczynienie osądu sumienia gwarantem

${ }^{27}$ Freidson (1999): 124.

${ }^{28}$ Ze względu na fundamentalne znaczenie tego przepisu dla profesjonalizmu lekarskiego przywołam oryginal w całości: "A Physician should not only be ever ready to obey the calls of the sick, but his mind ought also to be imbued with the greatness of his mission, and the responsibility he habitually incurs in its discharge. Those obligations are the more deep and enduring, because there is no tribunal other than his own conscience, to adjudge penalties for carelessness or neglect. Physicians should, therefore, minister to the sick with due impressions of the importance of their office; reflecting that the ease, the health, and the lives of those committed to their charge, depend on their skill, attention and fidelity. They should study, also, in their deportment, so to unite tenderness with firmness, and condescension with authority, as to inspire the minds of their patients with gratitude, respect and confidence".

${ }^{29}$ Ibidem: 127.

30 Baker (2013): 13.

31 Ibidem: 182. 
autonomii profesjonalnej lekarzy wiąże się z wymogiem należytego podkreślania wagi urzędu medyka w służbie choremu i znaczenia zachowania konsyliarza dla profesjonalnej relacji lekarz - pacjent. Autonomia sumienia została w analizowanym przepisie silnie powiązana z doskonałością profesjonalną: umiejętnościami lekarzy oraz ich troską o pacjenta i obowiązkiem wierności, a także ze służbą choremu jako odpowiedzią na jego wezwanie. Nie jest do końca jasne czy redaktorzy Kodeksu mają na myśli sumienie profesjonalne, czy też własne (osobiste). Podstawą pierwszego jest profesjonalna etyka lekarska bądź szerzej - moralna tradycja medycyny. Drugi rodzaj czy też funkcja sumienia ma swe źródła w pozaprofesjonalnych przekonaniach jednostki, między innymi w religii czy jej doświadczeniu życiowym ${ }^{32}$. Za potraktowaniem sumienia jako własnego przemawia fraza użyta $\mathrm{w}$ dokumencie (his own conscience). Za przyznaniem mu funkcji sumienia profesjonalnego - obudowanie frazy licznymi profesjonalnymi obowiązkami i wartościami, także instytucjonalnymi (wielkość urzędu). Pośredniego usprawiedliwienia dla tezy o profesjonalnej naturze sumienia w Kodeksie można szukać w przekonaniu T. Percivala o dominacji moralnego autorytetu profesji nad indywidualnym sumieniem lekarzy ${ }^{33}$.

Wartą wymienienia nowością w moralnej tradycji medycyny są unormowania paragrafów 4. i 5. Obowiązków lekarzy wobec pacjentów. W pierwszym redaktorzy ostrzegają przed pochopnym przekazywaniem pacjentowi „ponurych rokowań. Paragraf 5. ustanawia zakaz „opuszczania pacjenta nawet, gdy lekarz jego przypadek uważa za nieuleczalny". Oba przepisy ujmowane razem mają dalekosiężne konsekwencje dla profesjonalizmu klasycznego. Otaczając umieranie i śmierć zasłoną milczenia (paragraf 1.) i zakazując opuszczania umierającego (paragraf 2.), Kodeks AMA poddaje kres życia władzy lekarzy. Daje tym samym normatywne ramy dla rozpoczynającego się w połowie XVIII wieku procesu medykalizacji śmierci ${ }^{34}$. Jednym z jej przejawów jest marzenie $\mathrm{o}$ „technologicznej nieumieralności”, którą jakoby zapewnią postępy medycyny ${ }^{35}$.

Omawiany dokument był milczącą czterostronną etyczną umową społeczną między lekarzami, pacjentami, profesją i społeczeństwem ${ }^{36}$. Zgodnie z zasadą wzajemności nakładała ona obowiązki na lekarzy wobec pacjentów, ale zarazem obarczała pacjentów zobowiązaniami wobec lekarzy. Te ostatnie są spisane w rozdziale I. Kodeksu. Natomiast w rozdziale III wymienione są powinności profesji wobec społeczeństwa (public). Towarzyszą im obowiązki społeczeństwa wobec stanu lekarskiego. Autorytet profesjonalny medyków oparł się na autorytecie profesji, uprawniając ich jednocześnie do oczekiwania pomocy ze strony profesjonalnych organizacji, a także do żądania szacunku od społeczeństwa i do podporządkowania się jego członków profesjonalnym zaleceniom lekarzy. Dzięki kontraktowi profesjonalizm nabiera w pełni wymiaru społecznego i wymiar ten potwierdza. Jak pisze Troyen Brennan, profesjonalizm wręcz „symbolizuje kontrakt pomiędzy wysokowykwalifikowanymi lekarzami i społeczeństwem”37.

\footnotetext{
32 Kaldjian (2014): 137.

33 Baker, Caplan, Emanuel, Latham (1999): XVI.

34 Por.: Szewczyk (1996): 20-24.

35 Thomas (1991): 159.

36 Baker (1999): 36.

37 Brennan (2002): 979.
} 
Jednym ze skutków etycznego kontraktu społecznego było instytucjonalne związanie $\mathrm{z}$ profesjonalizmem tradycyjnym skrajnie mocnego paternalizmu ${ }^{38}$. Zasada wzajemności zderza się w Kodeksie z czymś, co można nazwać zmedykalizowaną postacią moralności honoru angielskiego dżentelmena. Tezę tę zilustruję fragmentem paragrafu 6. Artykułu II. Obowiązki pacjentów wobec lekarzy. Zgodnie z nim, posłuszeństwo pacjenta wobec zaleceń lekarza „powinno być bezzwłoczne i bezwarunkowe”. Lekarz nigdy nie powinien pozwolić, aby „amatorskie (crude) opinie” pacjenta „tyczące sprawności zdrowotnej wpływały na świadczoną mu opiekę". Lekarz ma prawo żądać tak bezwzględnego posłuszeństwa, gdyż - jak stanowi paragraf 1. cytowanego artykułu - jest ono jedną z form odwzajemnienia się lekarzowi za wiele „ważnych i ciężkich obowiązków względem społeczności”. Ich wypełnianie nierzadko wymaga "rezygnacji z wygody, spokoju i zdrowia dla dobrostanu zgłaszających się po świadczenia”. Swoistą zapłatą za samopoświęcenie lekarza jest posłuszeństwo pacjenta ordynacjom medyka. Z drugiej strony samopoświęcenie staje się usprawiedliwieniem moralnym skrajnej postaci paternalizmu.

Bardzo ważne dla (samo)definiowania profesji lekarskiej były cztery uregulowania instytucjonalne: par. 1. i 3. art. I Obowiązków profesji względem społeczeństwa oraz dwa uregulowania rozdziału II, mianowicie par. 1. art. I i par. 1. art. VI. Pierwszy z wymienionych przepisów nakazuje lekarzom wykonywać swoją pracę również w czasie epidemii chorób zakaźnych oraz łagodzić cierpienia chorych nawet jeśli wiąże się to "z zagrożeniem ich życia”. Natomiast par. 3. nakłada na lekarzy powinność leczenia ubogich, których nie stać na opłacenie świadczenia. Lekarz musi „zawsze wykonywać je chętnie i bezpłatnie”. Dwa ostatnie przepisy stoją na straży dobrego imienia i spoistości społeczności lekarskiej. Par.1. art. I przestrzega członków profesji przed kierowaniem "obelżywych, sarkastycznych" uwag pod adresem innych lekarzy. Natomiast par. 1. art. VI. nakazuje "szczególną powściągliwość” w ujawnianiu laikom „zagadnień profesjonalnych". Wiele takich problemów mogłoby bowiem nie zostać przez nich właściwie "zrozumianych i ocenionych".

W par. 1. i 3. art. I Obowiązków profesji względem społeczeństwa mówi się o „braterstwie profesjonalnym". Jego wyrazem jest między innymi bezpłatna opieka medyczna nad braćmi-lekarzami i ich rodzinami. Gildia kupiecka jako pierwowzór profesji stała się korporacją wspierających się braci profesjonalistów mających obowiązek dobroczynienia, przede wszystkim ratowania życia i utrzymywania zdrowia innych nawet kosztem utraty dochodu, a nawet za cenę utraty własnego życia. Efektem braterstwa profesjonalistów i wspólnoty obowiązków (wartości, poglądów) jest powstanie w medycynie silnej „tożsamości wspólnotowej”39. Stanowi ona bardzo ważny wyróżnik profesjonalizmu lekarskiego.

Wpływ Kodeksu z 1847 widać w uchwalonych w 1884 roku przez Towarzystwo Warszawskie Lekarskie Zasadach obowiązków i praw lekarzy ${ }^{40}$. Znajdują się w nich także regulacje dotyczące Stusznych wymagań lekarzy od publiczności. Nastawienie paternalistyczne jest w nich bodaj silnej zaakcentowane niż w dokumencie AMA. Art. 9. Zasad stanowi: „Z natury swojego stosunku do chorego lekarz zyskuje nad nim przewage mo-

\footnotetext{
38 Por. też: De (2004).

39 Coulehan (2005): 893.

40 Tulczyński (1975): 85-94.
} 
ralną. Wpływu tego lekarzowi nadużywać nie wolno". Zauważmy, redaktorzy mówią o przewadze moralnej, a nie związanej z wiedzą i sztuką medyczną, co byłoby bardziej zrozumiałe. Niestety, nie pojawia się tu uzasadnienie owej dominacji moralnej lekarza.

Reasumując: Rozważania nad profesjonalizmem klasycznym pokazują, że ma on dwa zasadnicze składniki czy też dwie strony ${ }^{41}$. Pierwszą buduje tradycja moralna sięgająca J. Gregory'ego i T. Percivala oraz sama instytucja medycyny regulowana przepisami Kodeksu z 1847 roku, a także swoisty dla niej etos, np. wspomniana postawa nabierająca wręcz znamion pracoholizmu. Drugą stroną jest etyka indywidualnych praktyków. W profesjonalizmie tradycyjnym etyka postępowania i obowiązku dominuje wyraźnie nad etyką charakteru (cnót), co potwierdzają sformułowania Kodeksu. Rozważania te pokazują również, że z profesjonalizmem tradycyjnym nierozłącznie związane są: altruizm graniczący z samopoświęceniem, dążenie do perfekcji, silne poczucie profesjonalnej wspólnotowości, skrajny paternalizm oraz etyka kodeksowa stanowiona kolegialnie i autonomicznie przez profesjonalistów. Dokonana rekonstrukcja profesjonalizmu sygnalizuje także obecność jego potencjalnie niebezpiecznych właściwości. Zrozumiałe i częściowo przynajmniej usprawiedliwione w rewolucyjnym czasie kształtowania się etyki lekarskiej i profesjonalizmu w medycynie, w obecnych warunkach kulturowych stają się anachroniczne i tworzą, jak ją nazywa E. Erde, ciemną stronę profesjonalizmu ${ }^{42}$.

\section{1.c. Złote lata medycyny amerykańskiej - ostrzeżenie przed ciemna strona profesjonalizmu}

Ciemna strona profesjonalizmu w pełni ujawniła się po około stu latach od przyjęcia Kodeksu w okresie zwanym złotymi latami amerykańskiej medycyny. W tym czasie wiele norm moralnych regulujących zachowanie medyków było „blisko spokrewnionych” z zasadami etyki instytucjonalnej Kodeksu z $1847^{43}$. Za E. Freidsonem na pierwszym miejscu przywołam skrupulatnie przestrzegany zakaz krytykowania kolegów, nawet wewnątrz środowiska lekarskiego. Był on również uwzględniany przez sądy, co w efekcie prowadziło do swoistej „zmowy milczenia” pozwalającej na odrzucanie opinii ekspertów w przypadkach błędów lekarskich. Informacja uzyskana od pacjentów w trakcie leczenia była zazwyczaj przechowywana przez lekarza, stanowiąc w rzeczywistości jego własność prywatną niedostępną nawet choremu. Wszelkie dyskusje lekarzy na tematy etyczne, kliniczne i finansowe były starannie chronione przed wydostaniem się do publiczności laików. Świadczenie usług ubogim pozostawiano w gestii indywidualnego sumienia.

Wzmocniona została także obecna w Kodeksie tendencja do izolacji profesji od wpływów zewnętrznych. Umocnieniu autonomii na poziomie instytucji i profesjonalnej kultury towarzyszyło podkreślanie dyskrecji personalnej lekarzy w relacjach z pacjentami i swobody w podejmowaniu decyzji moralnych, którą za R. Bakerem zasadnie nazwać można leseferyzmem moralnym ${ }^{44}$. Podstawę normatywną dała mu sekcja 2. rozdziału I.

41 Erde (2013): 185.

42 Erde (2008): 7.

43 Freidson (1999): 129-130.

44 Baker (2013): 221. 
uchwalonych w 1912 roku Zasad etyki lekarskiej ${ }^{45}$. Pozwala ona w etycznie trudnych przypadkach działać lekarzowi zgodnie z własnym sumieniem.

Z podobną postawą spotykamy się także w polskim środowisku lekarskim. Józef Bogusz w 1985 roku nauczał studentów i lekarzy, jak postępować z (dorosłymi) Świadkami Jehowy odmawiającymi transfuzji krwi. Przed operacją obiecał pacjentowi, że bez względu na okoliczności „krwi nie przetoczy”. Taką obietnicę złożył także żonie chorego. „Bezpośrednio przed operacją - opowiada zdarzenie J. Bogusz - przypomniałem personelowi biorącemu udział w operacji o obowiązku bezwzględnego zachowania w tajemnicy tego, co się dzieje na sali operacyjnej, szczególnie o obowiązku nieujawniania ani choremu, ani jego żonie faktu przetoczenia krwi, gdyby zostało ono wykonane. Byłem bowiem zdecydowany przetoczyć krew, gdyby w czasie operacji powstała sytuacja zagrożenia życia z powodu utraty krwi”. Opisywany przypadek autor zaliczył „do rzędu tych zagadnień natury etyczno-prawnej, wobec których każdy chirurg sam musi zająć stanowisko, a nie powinien i nie może przesuwać ciężaru odpowiedzialności na innych" ${ }^{46}$.

Zadekretowane w Kodeksie odwołanie się lekarza do sumienia było obwarowane wieloma powinnościami profesjonalnymi. W tak zwanym „złotym okresie” przekształciło się ono w leseferyzm moralny. Przykład J. Bogusza ukazuje analogiczną samowolę moralną jakiejś części elit także polskiego środowiska lekarskiego. Jej odwrotną stroną była samotność moralna lekarzy odwołujących się do sumienia indywidualnego. Mocny już w Kodeksie paternalizm sięgnął poziomu manipulowania pacjentem i uprzedmiatawiania go. Nasiliły się i okrzepły tendencje izolacjonistyczne i autarkiczne początków budowania profesjonalizmu i zaczęły służyć, nierzadko jako zmowa milczenia, ochronie przywilejów już ukształtowanej profesji i przede wszystkim jej członków.

\section{Profesjonalizm odbudowany i nowa etyka lekarska}

\section{2.a. Czynniki warunkujące powstanie profesjonalizmu odnowionego}

Złoty okres medycyny amerykańskiej trwał mniej więcej do połowy lat 60. ubiegłego wieku. Od tego czasu coraz większy wpływ na medycynę zaczęły mieć okoliczności "rujnujące" ${ }^{47}$ jej tradycyjne praktykowanie. W literaturze przedmiotu największą moc destrukcyjną przyznaje się nowym formom finansowania opieki zdrowotnej (czynnikom ekonomicznym), przede wszystkim prywatnym i publicznym ubezpieczeniom społecznym, w szczególności tzw. koordynowanej opiece zdrowotnej (managed health care) ${ }^{48}$. Jak pisze George Beaton, z jej powstaniem zaczął się „dyktat” nakazujący praktykom „,za co należy płacić i komu" ${ }^{49}$. Lekarze, stracili znaczną część swojej niezależności klinicznej i ekonomicznej. Natomiast pacjenci przestali wybierać lekarzy poszukując ich przede wszystkim na listach sporządzanych przez towarzystwa ubezpieczeniowe. Niektóre z towarzystw określają nawet sposób leczenia pacjenta i to bez konieczności uprzedniej

\footnotetext{
45 American Medical Association (1999): 346.

46 Bogusz (1985): 96-97.

47 Freidson (1999): 130.

48 Więcej na temat koordynowanej opieki zdrowotnej: Kowalska, Kalbarczyk (2013).

49 Beaton (2010): 20.
} 
wizyty chorego u lekarza. Wymienione sposoby finansowania pracy lekarza z chorym kształtują coraz powszechniejszy obraz medycyny, w którym doktor jest traktowany jako osoba „rozdzielająca towary” pomiędzy pacjentów. Również sama wizyta pacjenta staje się towarem nabywanym przez niego. Opieka koordynowana i inne formy uprzedniej płatności położyły nacisk na rachunek kosztów i korzyści. W mocno krytycznej ocenie Erica Cassella - lekarza i etyka medycyny o orientacji klasycznej - tradycyjna „idea medycyny jako profesji relacyjnej przyznającej kluczowe znaczenie relacji między lekarzem i pacjentem straciła aktualność" (kursywa w oryginale) ${ }^{50}$.

Społeczeństwo amerykańskie zaczęło traktować coraz lepiej zarabiających lekarzy specjalistów jak przedsiębiorców lekceważących stronę moralną profesji1 ${ }^{51}$. W takim ich postrzeganiu miało udział torpedowanie przez AMA prób budowania publicznej opieki zdrowotnej. W pewnym sensie stosunki między medykami i pacjentami zaczęły przypominać relacje biznesowe z okresu przed narodzinami profesjonalizmu, co spowodowało znaczną erozję zaufania pacjentów do profesji medycznej. Jest ono już od wielu lat niższe w USA niż w większości rozwiniętych krajów świata. Badania opublikowane w 2014 roku sytuują Stany Zjednoczone na piątym od końca (24) miejscu w rankingu tej wartości. Dodam na marginesie, że Polska zajęła w nim ostatnie (29) miejsce ${ }^{52}$.

Do zaakcentowanej przez E. Cassella przemiany w etyce praktykowania medycyny podważającej tradycyjny profesjonalizm walnie przyczyniły się także okoliczności prowadzące do powstania nowego typu etyki lekarskiej i samo jej pojawienie się. Istotna dla jej ukształtowania się była „prohibicja moralna”. Tak R. Baker nazwał postawę AMA programowo unikającego wiążących wypowiedzi i interpretacji tyczących aktualnych wówczas zagadnień etyki lekarskiej ${ }^{53}$. O jej oddziaływaniu świadczy fakt, że jeszcze w 1972 roku w amerykańskich szkołach medycznych nie było żadnego kursu etyki lekarskiej. Prohibicja tworząc próżnię aksjologiczną umożliwiła wypełnienie jej nową myślą etyczną. Zaczęli ją współtworzyć w przeważającej większości fachowcy w innych niż medycyna dziedzinach: teolodzy, filozofowie, prawnicy i socjologowie ${ }^{54}$.

Tę nową etykę lekarską na medyczne uczelnie amerykańskie zaczęto wprowadzać pod koniec lat 70. Wkrótce zyskała ona status dominującego sposobu wykładu etyki lekarskiej. Miała także ambicję zastąpienia w klinice dotychczasowej tradycyjnej etyki praktykowania medycyny. E. Erde nazywa ją „świecką akademicką etyką lekarską" ${ }^{55}$. Pojawia się też określenie „etyka postmodernistyczna" 56. Pierwszym podręcznikiem nietradycyjnej etyki lekarskiej było opracowanie Toma Beauchampa i Jamesa Childressa Principles of biomedical ethics z 1979 roku. Od tego czasu jak pisze R. Veatch, zaczęliśmy „nazywać ją etyką biomedyczną lub po prostu bioetyką" ${ }^{57}$. Określenie ukute przez E. Erde jest według mnie trafniejsze niż termin „bioetyka”, chociaż o wiele mniej popu-

\footnotetext{
${ }^{50}$ Ibidem.

${ }^{51}$ Wyjątek stanowili lekarze rodzinni, cieszący się dużym szacunkiem społecznym, por.: Lindemann

Nelson, Lindemann Nelson (1995): 19.

52 Blendon, Benson, Hero (2014).

${ }^{53}$ Baker (2013): 278.

${ }^{54}$ Por.: Szewczyk (2016): 35-38.

${ }^{55}$ Erde (2013): 184.

${ }^{56}$ Capron (1999): 186.

57 Veatch (2006): 587.
} 
larne. Bioetyka jest metodologiczne przepołowiona na dyscyplinę akademicką i dyskurs publiczny ${ }^{58}$ mający bardzo pośrednie odniesienie do etyki praktykowania medycyny. Nazwa „bioetyka” jest zatem zakresowo zbyt szeroka.

Etyka akademicka odwołująca się do negatywnych i pozytywnych praw pacjenta daje odpowiedzi nierzadko sprzeczne z duchem tradycyjnej kultury medycznej opartej na zobowiązaniach lekarzy względem chorych i pielęgnującej ideał paternalistycznie dobroczynnego medyka. Jej rozstrzygnięcia często są także niezgodne z pojmowaniem przez „sumiennego praktyka znaczenia autonomii profesjonalnej” ${ }^{59}$, szczególnie ukształtowanej w złotym okresie medycyny. Tytułem przykładu: opisane w podpunkcie 1.b. oddanie umierania we władzę lekarzy i otoczenie go zasłoną milczenia sprawiło, że tradycyjny profesjonalista niechętnie godzi się ze śmiercią chorego i jeszcze bardziej niechętnie oddaje decyzję o zaprzestaniu leczenia podtrzymującego życie w ręce pacjenta jak nakazuje świecka etyka akademicka. W orzeczeniu w sprawie Karen Quinlan z 1976 napisano: „Wydaje się, że nie tylko opiekujący się nią lekarze, ale także wielu wykwalifikowanych ekspertów powołanych na świadków było zgodnych, że odłączenie [pacjentki] od respiratora nie odpowiadało praktyce lekarskiej, jej standardom i tradycji". Podkreślę, że chora była w stanie przetrwale wegetatywnym a „realistycznie oceniane szanse na jej wyzdrowienie były całkowicie nieprawdopodobne ${ }^{\prime 60}$. Wniosek o zaprzestanie wentylowania złożył jej prawny opiekun.

Warto także wspomnieć, że etyka akademicka zaakceptowała przywilej wyboru pacjenta przez lekarza. Jest on niezgodny z etosem profesjonalizmu tradycyjnego. Wprowadziły go Zasady z 1912 roku. Sekcja 4. rozdziału 1. tego dokumentu daje lekarzowi taką wolność (z wyjątkiem sytuacji nagłych oraz okoliczności, w których umiarkowana opinia publiczna oczekuje od niego takich świadczeń). Następne nowelizacje Zasad będą potwierdzały to uprawnienie. Wspominane wcześniej polskie Zasady obowiązków i praw lekarzy podobny przywilej wprowadzają już w 1884 roku.

Nowa etyka akademicka przyczyniła się do bardzo krytycznie ocenianej przez E. Cassella przemiany medycyny z profesji praktykowanej dla chorego w działanie podejmowane wspólnie z nim, pomagające mu w powrocie do zdrowia ${ }^{61}$. Zgodnie z jej zasadami lekarze na poziomie decyzji klinicznych nie ustalają już samodzielnie sposobów postępowania z pacjentami. Praktycy jedynie „inicjują naradę” dotyczącą takiego postępowania, jego planu i priorytetów, w której wraz z nimi uczestniczą pacjenci i jeśli to konieczne - inne osoby zaangażowane w przypadek $^{62}$. Stawianie na pierwszym miejscu przez etykę akademicką zasady poszanowania autonomii pacjenta, graniczące $\mathrm{z}$ „obsesją"63 na jej punkcie, jest interpretowane jako rezultat wspomnianej utraty przez społeczeństwo zaufania do lekarzy: im mniej się ufa profesjonalistom, tym bardziej ogranicza się ich wolność. W tej sytuacji Alfred Tauber proponuje, aby profesja lekarska

\footnotetext{
${ }^{58}$ Łuków (2017): 403; Szewczyk (2013): 251.

${ }^{59}$ Erde (2013): 185.

60 "It seemed to be the consensus not only of the treating physicians but also of the several qualified experts who testified in the case, that removal from the respirator would not conform to medical practices, standards and traditions". In re Quinlan.

${ }_{61}$ Cassell (2013): 22.

62 Łuków (2017): 405.

${ }^{63}$ Callahan (1984): 42.
} 
"zrewidowała własne standardy i lepiej dopasowała się do bardziej tradycyjnych i fundamentalnych wartości opieki nad pacjentami" ${ }^{64}$. Jest to właściwie apel o odnowienie profesjonalizmu klasycznego.

Po wprowadzeniu do szkół medycznych nowej etyki lekarskiej zaczęto badać jej wpływ na studentów, zakładając, że będzie on pozytywny. Tymczasem uzyskiwane wyniki wyraźnie wskazywały na niepokojące obniżanie się klinicznej wrażliwości moralnej słuchaczy. Zjawisko to nie ogranicza się wyłącznie do amerykańskich uczelni medycznych ${ }^{65}$. Pod wpływem artykułu Frederica Hafferty' ego i Ronalda Franksa z roku $1994^{66}$ główną przyczynę niepowodzeń edukacyjnych formalnie wykładanej akademickiej etyki zaczęto upatrywać w tzw. kursie ukrytym silnie formacyjnie oddziałującym na adeptów medycyny i młodych lekarzy. Skutecznym remedium na moralną atrofię kandydatów na lekarzy miało być już nie tyle nauczanie nowej etyki lekarskiej, ile zwrot ku profesjonalizmowi i kształtowanie profesjonalnej postawy słuchaczy, formowanie ich profesjonalnego charakteru i sumienia.

Na koniec przywołam jeszcze jedną okoliczność mogącą się przyczynić do zainteresowania świata lekarskiego profesjonalizmem. Ma ona charakter socjologiczny, a jest nią dostrzeżona przez R. Bakera niechęć medyków do wszelkich zewnętrznych wobec profesji autorytetów moralnych i poczucie zagrożenia wywoływane ich obecnością ${ }^{67}$. Nowa etyka lekarska jest często odbierania jako takie właśnie zewnętrzne zagrożenie i próba zamachu na autonomię moralną świata lekarskiego. Obserwację tę potwierdza moja wieloletnia praktyka nauczyciela etyki lekarskiej na uczelni medycznej.

\section{2.b. Profesjonalizm odnowiony - cnoty i zachowania profesjonalne}

Opisane w poprzednim podpunkcie czynniki rujnujące tradycyjne praktykowanie medycyny skłoniły reformatorsko zorientowanych lekarzy i profesjonalne organizacje medyczne do apeli o "odnowienie” zainteresowania profesjonalizmem ${ }^{68}$, prowadzące do „odnowienia” jego sensu ${ }^{69}$. Intensywność tego wołania wzmacniało rosnące napięcie między etyką akademicką a profesjonalizmem tradycyjnym, przeradzające się jak sugeruje E. Erde w „bitwę gigantów" ${ }^{\prime 70}$. Wtórują mu Colleen Clements i Roger Sider, mówiąc $\mathrm{o}$ „ataku” tej etyki na „system historycznych wartości lekarskich"71.

Mizerne sukcesy nowej etyki akademickiej w formowaniu moralnym studentów i rezydentów pospołu z odkryciem destrukcyjnego wpływu na to kształcenie kursu ukrytego i pozostałych kursów pozaformalnych nie ujętych w oficjalnych (formalnych) sylabusach ${ }^{72}$, dało temu odradzającemu się profesjonalizmowi wyraźny rys aretologiczny. Trud dużej części jego zwolenników skupia się na sporządzaniu katalogu cnót

${ }^{64}$ Tauber (2005): 7.

${ }^{65}$ Zob.: Szewczyk (2018): 63-64.

${ }^{66}$ Hafferty, Franks (1994).

67 Baker (2013): 231-279; Montgomery (2016): 12.

${ }^{68}$ Swick (2000): 615.

${ }^{69}$ ABIM Foundation, ACP-ASIM Foundation, European Federation of Internal Medicine (2002): 243.

${ }^{70}$ Erde (2013): 201-202.

${ }^{71}$ Clements, Sider (1983): 2011.

72 Szewczyk (2018): 63. 
dobrego lekarza i sposobach właściwego kształtowania jego profesjonalnego charakteru. Istotę aretologicznej strony odnowionego profesjonalizmu ujmują Howard Brody i David Doukas, pisząc, że profesjonalizm jest „aplikacją cnoty do profesji w opiece zdrowotnej” ${ }^{\prime 7}$. Podobnie sądzi E. Erde, dla którego „profesjonalizm stanowi odmianę teorii cnót antycznego greckiego paradygmatu" ${ }^{\prime 4}$. Jednakże, jak głosi tytuł monografii pod redakcją Nuali Kenny i Wayne Sheltona, jest to „cnota utracona” i zadaniem profesjonalizmu odnowionego jest jej odzyskanie ${ }^{75}$.

"Schemat ideowy" profesjonalizmu tradycyjnego i odnowionego jest taki sam. Ukazuje on dwie ich strony: wewnętrzną i zewnętrzną. Pierwsza jest "mikrokosmosem” etosu indywidualnych lekarzy, druga - mającym własną integralność „makrokosmosem” tradycji moralnej profesji, jej kultury korporacyjnej i instytucji medycznych ${ }^{76}$. W prehistorii profesjonalizmu mikrokosmos tworzyły etyka cnót i charakteru dobrego lekarza. Makrokosmosem była medycyna jako profesja zaufania publicznego kultywująca zasady honoru dżentelmeńskiego i paternalizmu arystokratycznego. Kodeks z 1847 zastępuje etykę cnót etyką postępowania i obowiązku. Jest to zdaniem R. Bakera zmiana rewolucyjna w etyce lekarskiej ${ }^{77}$. Odtąd mikrokosmos indywidualnych lekarzy będzie w profesjonalizmie tradycyjnym sferą obowiązku i profesjonalnego postępowania (zachowania się), choć rozważania o etyce charakteru nie znikną z niego całkowicie. Etyka instytucjonalna Kodeksu wzbogaci makrokosmos profesjonalizmu. Utrwali w nim i wzmocni arystokratyzm moralny sięgający moralnej megalomanii oraz złączy go z wolnością decyzyjną lekarzy i autonomią profesji graniczącą z autarkizmem. Samopoświęcenie kultura profesjonalizmu tradycyjnego z czasem zmieni z cnoty w kult pracy bliski pracoholizmowi.

Zwolennicy profesjonalizmu odnowionego jako aplikacji teorii cnót w znacznej mierze „odnawiają" prehistorię profesjonalizmu, warunek dobrego doktorzenia ${ }^{78}$ widząc w charakterze lekarza. E. Erde sądzi, że w tej formie profesjonalizmu zasadniczą cechą charakteru jest usposobienie (disposition) do „utrzymywania życia i maksymalizowana zdrowia ${ }^{79 \prime \prime}$ (autor zapisuje ten sąd kursywą i czcionką pogrubioną). Można się domyślać, że pozostałe cnoty profesjonalne służą realizacji tej naczelnej dyspozycji. Opisane w podpunkcie 1.c. postępowanie J. Bogusza z operowanym Świadkiem Jehowy stanowi bardzo dobrą ilustrację przywołanego poglądu. Lekarz ten sądzi, że profesjonalista winien zabiegać o utrzymanie życia chorego, nawet jeśli jest to okupione oszustwem, pogwałceniem wolności religijnej i zmuszaniem podwładnych do uczestnictwa $\mathrm{w}$ tym procederze. Jest to niewątpliwie pogląd skrajny. Mniej radykalni tradycjonaliści spełnienie woli chorego w podobnych sytuacjach okupują dyskomfortem moralnym i poczuciem sprzeniewierzenia się fundamentalnemu profesjonalnemu obowiązkowi ratowania życia ${ }^{80}$. Normatywną podstawę skłonności do utrzymywania życia i maksymalizowania

\footnotetext{
${ }^{73}$ Brody, Doukas (2014): 983.

${ }^{74}$ Erde (2013): 185.

${ }^{75}$ Kenny, Shelton: (2006).

76 Por.: Erde (2013): 185.

77 R. Baker (1999): 36.

${ }^{78}$ Zdecydowałem się tak właśnie spolszczyć angielskie good doctoring, traktując tę frazę jako odpowiednik słowny "dobrego gospodarzenia” czy też „włodarzenia”. Zob. też: Szewczyk (2018): 62.

${ }^{79}$ Erde (2013): 185.

${ }^{80}$ Zob.: Szewczyk (2009): 170.
} 
zdrowia dały omawiane w podpunkcie 1.b. dwie regulacje Kodeksu, mianowicie paragrafy 4. i 5. Obowiązków lekarzy wobec pacjentów. Wiara w postęp naukowy i technologiczny medycyny kulminująca się w nadziei na technologiczną nieumieralność sprawia, że lekarze zaczynają walczyć już nie tyle o życie i zdrowie (dobrostan zdrowotny) chorego, ile o jego przeżycie, nawet kosztem wzrostu bólu i cierpienia. Ta zmiana nastawienia w profesjonalizmie dokonuje się w pełni po drugiej wojnie światowej ${ }^{81}$.

Autorzy opowiadający się za profesjonalizmem jako etyką cnót zainteresowani są przede wszystkim formacyjnym aspektem profesjonalizmu. Ich zdaniem celem edukacji profesjonalnej jest rozwój charakteru dobrego lekarza. Jednakże duża grupa autorów nie odwołuje się do etyki cnót. Skupiają się oni na poznawczych (kompetencyjnych) aspektach profesjonalizmu - na znajomości i zrozumieniu wartości, zachowań i zasad regulujących praktykę lekarską i ją przenikających ${ }^{82}$. Do tej drugiej orientacji należy Herbert Swick. W swoim artykule będącym w ocenie F. Hafferty'ego i D. Levinson "godnym uwagi osiągnięciem" ${ }^{\prime 83}$ przedstawia katalog zachowań profesjonalisty ${ }^{84}$. Stanowi on wyciąg z literatury przedmiotu oraz z dokumentów organizacji lekarskich. Równocześnie artykuł ten wywarł wpływ na wielu autorów zajmujących się profesjonalizmem. Wyraźnie widoczny jest także w Karcie lekarza - manifeście profesjonalizmu odnowionego fazy instytucjonalnej.

H. Swick deklaruje na wstępie, że sposobem pozwalającym na ochronę autonomii profesjonalnej jest odbudowa "odrębnego głosu medycyny”. Jej początkiem ma być „wzmocnienie profesjonalizmu lekarzy”. Podane w artykule zachowania są według niego „podstawą, na której spoczywa profesjonalizm”. Równocześnie profesjonaliści, którzy je kultywują dowodzą, że są godni zaufania pokładanego w lekarzach przez pacjentów i społeczeństwo. Pierwsze dwa zachowania są powtórzeniem idei profesjonalizmu tradycyjnego. Wymienię je w kolejności: podporządkowanie własnych interesów lekarza interesom pacjenta, jako „kamień probierczy profesjonalizmu” oraz przywiązanie do wysokich standardów moralnych. Trzecie zachowanie nakazuje odpowiadać lekarzom na potrzeby społeczne. Obejmuje ono także świadczenie opieki pacjentom, których na nią nie stać oraz działania na rzecz dostępu do opieki zdrowotnej grup tradycyjnie pod tym względem zmarginalizowanych. Zachowanie to zapowiada już wyraźne w Karcie lekarza dążenie do sprawiedliwości społecznej. W tym znaczeniu uznać je można za nowość charakterystyczną dla profesjonalizmu odnowionego.

Czwartym zachowaniem jest postępowanie będące "przejawem wartości humanistycznych" łącznie z uczciwością i prawością, troską i współczuciem, altruizmem i empatią, szacunkiem dla innych i wiarygodnością. Zdaniem H. Swicka wartości humanistyczne są "kluczowe” dla pracy lekarza. W profesjonalizmie odnowionym także autorzy zgłaszający akces do teorii cnót sporządzają bardzo podobny wykaz predyspozycji charakteru dobrego lekarza ${ }^{85}$. Odwołania do humanizmu nie było w profesjonalizmie klasycznym. Niewykluczone, że nazywanie wartości przez H. Swicka humanistycznymi jest dziedzictwem Zasad 1912 roku mówiących o służbie lekarzy sprawowanej

\footnotetext{
81 Zob.: K. Szewczyk (2009): 68-69.

${ }^{82}$ Giubilini, Milnes, Savulescu (2016): 130.

${ }^{83}$ Hafferty, Levinson (2008): 602.

84 Swick (2000): 613.

${ }^{85}$ Giubilini, Milnes, Savulescu (2016): 130.
} 
dla ludzkości (humanity). Na piątym miejscu znajduje się odpowiedzialność lekarza za siebie i za kolegów (profesję) jako zachowanie niezbędne dla utrzymania profesjonalnej autonomii. Niezgodne z nim jest ukrywanie niewłaściwego praktykowania medycyny, także chronienie niekompetentnych lekarzy.

Szóste miejsce H. Swick przyznaje ustawicznemu dążeniu do doskonałości rozumianej tu jako perfekcja kliniczna osiągana przez nieprzerwaną edukację i ćwiczenie profesjonalnych umiejętności. Jest to niemal dosłowne nawiązanie do J. Gregory'ego i profesjonalizmu tradycyjnego. Nie ma tu jednak zastrzeżenia z Kodeksu z 1847 roku (par. 2. artykułu I. rozdziału II.). Przypomnę, że zgodnie z nim osiągnięcia naukowe i perfekcja kliniczna nie mogą ani zastąpić, ani zrównoważyć doskonałości moralnej. Na siódmej pozycji jest zachowanie edukacyjne. W jego skład wchodzą między innymi nowatorskie badania i wysiłki zmierzające do wdrożenia w praktykę najbardziej kosztowo efektywnej i skutecznej opieki zdrowotnej.

Ciekawą nowością jest zachowanie ósme. Przypomina, że lekarz pracuje w sytuacji „wysokiej złożoności i niepewności”. Profesjonalne zachowanie w takich okolicznościach polega na podejmowaniu decyzji niezależnych i nierutynowych. W ostatnim typie zachowań H. Swick profesjonalizm wiąże z „namysłem lekarzy nad ich działaniami i decyzjami”. Refleksja nad własną działalnością profesjonalną służy nie tylko ulepszeniu wiedzy i umiejętności lekarza. Prowadzi także do równoważenia życia profesjonalnego z osobistym. Ten pozorny banał jest w mojej opinii polemiką (implicite) z ugruntowanym $\mathrm{w}$ profesjonalizmie tradycyjnym etosem pracy bliskim pracoholizmowi. Nieobcy jest on także niektórym zwolennikom profesjonalizmu odnowionego: „Profesjonalizm, właściwie rozumiany, jest ciężką pracą" 86 .

Reasumując powiem, że zadaniem profesjonalizmu odnowionego w ujęciu $\mathrm{H}$. Swicka jest przywrócenie wielu zasad będących wyróżnikami profesjonalizmu tradycyjnego, przede wszystkim autonomii profesji ściśle powiązanej tu z odpowiedzialnością lekarza za siebie i kolegów. Cichym echem arystokratyzmu moralnego jest osadzenie relacji lekarz - pacjent w wartościach humanistycznych. Może ono być wykorzystywane do moralnej dominacji lekarza nad pacjentem. W sytuacji konfliktu między nimi mającego podłoże aksjologiczne lekarz może argumentować, że to właśnie on - nie pacjent - reprezentuje właściwe, bo humanistyczne, wspólne wszystkim ludziom wartości. Niebezpieczeństwo konserwowania nieusprawiedliwionego paternalizmu wzmacnia i ta okoliczność, że żadne z zachowań nie mówi o przestrzeganiu autonomii decyzyjnej pacjenta. Nie ma w katalogu zachowań odwołania do sumienia lekarza ani indywidualnego, ani profesjonalnego. Zwraca także uwagę brak tonu moralnej wyższości i moralnego puryzmu przenikających regulacje Kodeksu z 1847 roku. Pojawiają się w nim nowości, z działaniem lekarza na rzecz sprawiedliwości społecznej na czele.

\section{2.c. Instytucjonalny (organizacyjny) profesjonalizm odnowiony - Karta lekarza}

Profesjonalizm odnowiony doczekał się w 2002 roku instytucjonalnego wyrazu: jest nim zredagowany wysiłkiem American Board of Internal Medicine Foundation, American College of Physicians - American Society of Internal Medicine Foundation i European

${ }^{86}$ Brody, Doukas (2014): 982. 
Federation of Internal Medicine dokument Profesjonalizm lekarski w nowym milenium: Karta lekarza ${ }^{87}$. W 2013 roku Karta została spolszczona ${ }^{88}$.

W Preambule dokumentu redaktorzy stwierdzają, że profesjonalizm jest podstawą kontraktu medycyny ze społeczeństwem. Pogląd ten stanowi nawiązanie do „milczącego układu” Kodeksu z 1847 roku. „Korzenie” profesjonalizmu mają sięgać Hipokratesa. Jest to oczywisty błąd historyczny. Podstawy profesjonalizmu - jak pisałem - konstruowane były znacznie później, bo dopiero w XVIII wieku ${ }^{89}$. O ważności i trwałości kontraktu społecznego decyduje podporządkowanie się lekarzy sformułowanym w Karcie trzem zasadom podstawowym profesjonalizmu oraz wypełnianie podanych w niej dziesięciu kategorycznych zobowiązań (definitive responsiliblities) profesjonalisty. Przy szczegółowym omawianiu zobowiązań w dokumencie używa się terminu commitment, który można tłumaczyć również jako „oddanie”, ,zaangażowanie” czy „dążenie”. To ostanie spolszczenie sugeruje, że Kartę można czytać nie tylko w języku zasad i obowiązków. Dopuszczalna jest także jej interpretacja przy użyciu słownika wartości ${ }^{90}$. Przyjmując tę interpretację można powiedzieć, że zasady regulują poznawcze i kompetencyjne zadania profesjonalizmu. Natomiast dążenia przede wszystkim odnoszą się do wartości, którymi powinien kierować się dobry lekarz. Nie ma w tym dokumencie - podobnie jak u H. Swicka - odniesienia do etyki cnót. Listę zasad otwiera norma uznająca prymat (primacy) dobrostanu (welfare) pacjenta. Stanowi ona powtórzenie nakazu sięgającego początków profesjonalizmu i jest wiązana - także przez redaktorów Karty - z altruizmem ${ }^{91}$. Ten zaś jest niezbędny dla zaufania koniecznego w utrzymaniu relacji lekarz - pacjent.

Drugie pryncypium - zasada poszanowania autonomii decyzyjnej pacjenta - jest moim zdaniem radykalną nowością w historii profesjonalizmu. Osłabia ono poważnie tradycyjny paternalizm i stanowi ustępstwo na rzecz akademickiej etyki lekarskiej spod znaku T. Beauchampa i J. Childressa. Nadrzędna w tej etyce pozycja autonomii pacjenta została jednakże w Karcie obwarowana wymogiem zgodności z etycznym praktykowaniem (ethical practice) medycyny i zastrzeżeniem, że decyzje pacjenta nie mogą prowadzić do niewłaściwej nad nim opieki. Z powodu braku komentarza do tej zasady mogę się wyłącznie domyślać, że redaktorzy dokumentu przez użycie frazy „etyczne praktykowanie" chcą wskazać na ugruntowanie tego ograniczenia w etycznej tradycji medycyny. Poszanowanie autonomii decyzyjnej pacjentów jest wiążące dla lekarzy w granicach zakreślonych przez profesjonalizm w całej jego historii. Obwarowania te mogą mieć dwojaki skutek. Z jednej strony mogą się przyczynić do hamowania wspomnianego w podpunkcie 2.a. przekształcania się zasady poszanowania autonomii z prawa pacjenta w obsesję, z drugiej zaś - mogą konserwować postawę paternalistyczną lekarzy $\mathrm{w}$ ewentualnym konflikcie pryncypium poszanowania autonomii $\mathrm{z}$ ich usposobieniem do utrzymywania życia i maksymalizowania zdrowia, będącym - przypomnę - wiodącą cechą charakteru profesjonalisty. Takie same ograniczenia jak na pryncypium autonomii

\footnotetext{
${ }^{87}$ ABIM Foundation, ACP-ASIM Foundation, European Federation of Internal Medicine (2002).

${ }^{88}$ Karta lekarza (2013).

${ }^{89}$ Por. też: McCullough (2006): 18.

${ }^{90}$ Por. też: Inui (2003): 12.

${ }^{91}$ Zob. też na temat pojęcia altruizmu w relacji partnerskiej lekarz - pacjent: Michałowska, Turek (2010): 135.
} 
Karta nakłada na dążenie do szczerości w informowaniu pacjenta. Uwzględnia ono także zobowiązanie do ujawniania pacjentowi popełnionych błędów oraz ich raportowanie odpowiednim instytucjom. Zatajanie zdarzeń niepożądanych poważnie szkodzi i pacjentowi, i zaufaniu społecznemu do medycyny.

Trzecia w kolejności zasada sprawiedliwości społecznej zapowiadana jest w katalogu zachowań H. Swicka. Nakazuje ona profesji lekarskiej wspieranie sprawiedliwości w systemie opieki zdrowotnej. Pryncypium to stanowi wyraz ekspansywności odnowionego profesjonalizmu instytucjonalnego. Redaktorzy umieszczając je w Karcie wychodzą bowiem poza tradycyjny obszar etyki profesjonalnej ${ }^{92}$, sięgając instytucji publicznych zewnętrznych wobec medycyny. Takiego wyjścia wymagają szczególnie dwa zobowiązania poruszające tematykę sprawiedliwości, mianowicie dążenie lekarzy do poprawy dostępu do opieki zdrowotnej oraz dążenie do sprawiedliwej dystrybucji ograniczonych zasobów opieki zdrowotnej. Jak będę pisał niżej ta ekspansywność grozi destrukcją profesjonalizmu lekarskiego.

Za godną podkreślenia nowość profesjonalizmu odnowionego uznaję dążenie do utrzymania zaufania społecznego poprzez zarządzanie konfliktem interesów. Współcześnie jest to bardzo ważne i równie trudne w realizacji zobowiązanie. Do datującego się od czasów Hipokratesa konfliktu między dobrem pacjenta i interesem lekarza (i jego mistrza) dołączyło wiele innych sprzeczności. W Karcie wymienione są konflikty „najbardziej zagrażające” zaufaniu społecznemu. Pojawiają się w personalnych i instytucjonalnych kontaktach z przemysłem nastawionym na zysk, w tym z wytwórcami wyposażenia medycznego, firmami farmaceutycznymi, a także towarzystwami ubezpieczeniowymi. Zasygnalizowana nowość, jakkolwiek ważna dla instytucjonalnego profesjonalizmu odnowionego, nie jest jednak najważniejszym jego wyróżnikiem. Od profesjonalizmu tradycyjnego istotnie różnią go bowiem dwa pryncypia: zasada poszanowania autonomii i norma sprawiedliwości społecznej ${ }^{j 3}$.

\section{Profesjonalizm kompleksowy}

Pryncypium poszanowania autonomii zbliża Kartę do świeckiej etyki akademickiej. Natomiast normą sprawiedliwości społecznej dokument wkracza jak pokażę niżej w obszar profesjonalizmu kompleksowego. Można zatem stwierdzić, że profesjonalizm odnowiony w swoim wyrazie instytucjonalnym jest formą profesjonalizmu usytuowaną na granicy między akademicką etyką lekarską i profesjonalizmem kompleksowym. Ten ostatni stanowi konstrukcję teoretyczną budowaną przez F. Hafferty'ego, D. Levinson i Briana Castellaniego.

Profesjonalizm kompleksowy (systemowy) ${ }^{94}$ jest złożonym „systemem społecznym"95 łączącym siecią wzajemnych powiązań różne typy profesjonalizmu. Autorzy oprócz profesjonalizmu odnowionego (nazywając go nostalgicznym) opisują kolejne sześć wzajemnie konkurujących grup (clusters): profesjonalizm działacza (activist), akademicki (academic), badacza (empirical), profesjonalizm bezrefleksyjny (unreflective) lekarzy praktykujących poza ośrodkami akademickimi i niebędących badaczami oraz

\footnotetext{
${ }^{92}$ Hafferty, Levinson (2008): 603.

93 Zob. też: Kuczewski (2010): 33.

94 Castellani, Hafferty (2006).

95 Ibidem: 17.
} 
profesjonalizm przedsiębiorcy (entrepreneurial) i sposobu życia (lifestyle). Wszystkie siedem grup zostało jak piszą B. Castellani, F. Hafferty przez nich „empirycznie odkryte" ${ }^{\prime 96}$. Tak znaczne rozczłonkowanie profesjonalizmu jest według nich skutkiem działania sił zewnętrznych dezintegrujących jego dotychczasową względnie spójną całość. Najważniejsze z owych sił wymieniłem podpunkcie 2.a.

Profesjonalizm kompleksowy jest funkcją oddziaływań pomiędzy wymienionymi składnikami. Tworzą go dynamiczne relacje z szeroko rozumianym społecznym i politycznym otoczeniem. Innymi słowy, profesjonalizmu kompleksowego nie można sprowadzić jedynie do zachowań indywidualnych lekarzy (w szczególności motywowanych uwewnętrznionymi przez nich wartościami); choć ważne, są jednak „kwestią drugorzędną" ${ }^{97}$. Nie mieści się on także w strukturach organizacyjnych medycyny bądź zasadach ich funkcjonowania. Profesjonalizm kompleksowy istnieje (exist) w dynamicznej grze systemów zbudowanych z pracowników systemu opieki zdrowotnej, jego struktur i wielorakich wpływów otoczenia ${ }^{98}$. Normatywne zobowiązania profesjonalizmu kompleksowego wykraczają poza etykę praktykowania medycyny i etykę instytucjonalną, obejmując swym zasięgiem również instytucje państwa, np. polityczne. Sam zaś profesjonalizm jako wyraz oporu przeciwko ich dezintegrującym mocom, staje się częścią tych instytucji i sił społecznych.

Ekspansywność profesjonalizmu kompleksowego obecną już - jak pisałem w podpunkcie 2.c. - w profesjonalizmie odnowionym, najwyraźniej widać w profesjonalizmie działacza, dla którego nadrzędną wartością jest sprawiedliwość społeczna. Mianem tym można określić - według B. Castellaniego i F. Hafferty'ego - stosunkowo nieliczną grupę lekarzy zdrowia publicznego i medycyny społecznej zaangażowanych w kampanię na rzecz narodowego programu zdrowia oraz świadczących opiekę medyczną ubogim. Ich zobowiązanie (commitment) do ochrony zdrowia i dobrostanu pacjentów sytuuje się na „poziomie” znajdującym się „politycznie, ekonomicznie i co najważniejsze organizacyjnie poza granicami powszechnie uznawanego nurtu profesjonalnego" 99 . W opinii E. Erde, którą podzielam, takie wyjście poza główny nurt profesjonalizmu „burzy” profesjonalizm. Jest on bowiem ideologią kształtującą tych, którzy - jako grupa i grupy tej indywidualni członkowie - odpowiadają na głos chorych i cierpiących, a także informującą, jak spełniać to zadanie ${ }^{100}$. Lekarz podejmujący dyskusję na temat ekonomii zdrowia przejmuje funkcje ekonomisty. Podobnie lekarz zajmujący się sprawiedliwą organizacją systemu opieki zdrowotnej występuje w roli polityka, a nie profesjonalisty, sama zaś idea sprawiedliwości społecznej „nie ma [...] nic wspólnego z cnotą sprawiedliwości lekarza jako profesjonalisty" ${ }^{101}$. Profesjonalizm staje się tu wspomnianą wyżej częścią różnorakich instytucji państwa, a profesjonaliści fachowcami pracującymi na rzecz tych instytucji.

Profesjonalizm aktywisty według F. Hafferty'ego i D. Levinson znajduje się w rodzinie profesjonalizmów określanych takimi nazwami jak „demokratyczny” bądź „oby-

\footnotetext{
96 Ibidem: 4.

97 Hafferty, Levinson (2008): 604.

98 Ibidem: 610.

99 Castellani, Hafferty (2006): 17.

100 Erde (2013): 199.

101 Olejniczak (2015): 78.
} 
watelski" ${ }^{102}$. Pokrewieństwo zadań lekarza aktywisty z zadaniami obywatela i demokraty sprawia, jak sądzę, że profesjonalizm kompleksowy zaczyna przekształcać się w bioetyczny dyskurs społeczny. Albert Dzur stwierdza wprost, że „bioetyka jest dojrzałym demokratycznym ruchem profesjonalnym" ${ }^{\prime 103}$. Oprócz przejęcia przez instytucje państwa zewnętrzne wobec niego, profesjonalizmowi kompleksowemu zagraża zatem przekształcenie się w dyskurs bioetyczny. Konsekwencją takiego procesu jest niedemokratyczne zdominowanie profesjonalizmu przez bioetykę publiczną. Dlatego o wiele bliższy jest mi pogląd P. Łukowa. Zgodnie z nim profesjonalizm lekarski jest jednym z samodzielnych źródeł ożywiających bioetyczną debatę - jednym z „repozytoriów racji”, które będą w tej deliberacji oceniane z perspektywy demokratycznych ideałów i wartości ${ }^{104}$.

Do opisanych tendencji samobójczych profesjonalizmu kompleksowego dołączają dwie kolejne z edukacyjnego punktu widzenia niezwykle poważne wady. Są nimi: arbitralność podziału na poszczególne profesjonalizmy i bardzo znaczny poziom skomplikowania. Jego schemat ideowy przypomina pajęczynę utkaną z graficznych prezentacji trajektorii oddziaływań między znanymi nam częściami profesjonalizmu kompleksowego ${ }^{105}$. Skazy te sprawiają, że edukacyjna przydatność profesjonalizmu kompleksowego staje pod dużym znakiem zapytania, eufemistycznie rzecz ujmując. Dlatego w następnym punkcie ograniczę się wyłącznie do charakterystyki wad i zalet profesjonalizmu tradycyjnego i odnowionego, w dużej części wspólnych obu formom.

\section{Wady i zalety profesjonalizmu tradycyjnego i odnowionego}

\section{4.a. Wady profesjonalizmu tradycyjnego i odnowionego}

Istotną ich skazą jest dwuznaczność moralna. Cierpią na nią wszystkie profesjonalizmy, jednakże w lekarskim jest ona szczególnie niebezpieczna ze względu na władzę jego przedstawicieli nad naszym zdrowiem i życiem oraz na stopień medykalizacji społeczeństwa zachodniego. W radykalnym ujęciu tej wady profesjonalizm i kodeksy etyki profesjonalnej nie tyle służą ochronie interesów pacjentów (społeczeństwa), ile są skutecznymi środkami osłaniającymi profesjonalistów przed pacjentami (społeczeństwem) ${ }^{106}$. Ambiwalencja moralna profesjonalizmu tradycyjnego ujawniła się szczególnie jaskrawo w złotych latach medycyny amerykańskiej. Chociaż w postaci nieco osłabionej, dziedziczy ją również profesjonalizm odnowiony, w którym zdaniem krytycznie do niego nastawionych B. Castellaniego i F. Hafferty'ego autonomia decyzyjna lekarzy i profesjonalna dominacja sytuują się na pierwszym miejscu profesjonalnych wartości, wyprzedzając altruizm ${ }^{107}$.

Polskim przykładem dwuznaczności moralnej profesjonalizmu jest kazus Zofii Szychowskiej - lekarki na łamach prasy wypowiadającej się krytycznie o działaniach swojej przełożonej, także lekarki. Sądy zawodowe obu instancji uznały tę wypowiedź za jaskrawe

\footnotetext{
102 Hafferty, Levinson (2008): 606.

103 Dzur (2008): 208.

104 Łuków (2017): 408.

105 Hafferty, Castellani (2010): 293.

106 Brecher (2004): 4.

107 Castellani, Hafferty (2006): 9.
} 
naruszenie art. 52. ustęp 2. Kodeksu etyki lekarskiej zakazującego publicznego dyskredytowania innych lekarzy. Sprawa znalazła finał w Trybunale Konstytucyjnym. Sędziowie w kwietniu 2008 roku stwierdzili, że sądy lekarskie stosują przepis w sposób uproszczony. Przez publiczne dyskredytowanie rozumieją bowiem „każdą publiczną krytykę, nie badając powodów (motywów) jej wygłoszenia, ani też - co w sprawie [Z. Szychowskiej - K.Sz.] wydaje się zasadnicze - prawdziwości stawianych zarzutów" ${ }^{\prime 108}$. Każda zatem krytyczna wypowiedź pod adresem członków profesji, nawet zasadna, jest interpretowana przez środowisko lekarskie jako dyskredytująca lekarzy i naruszająca dobre imię profesji.

Nieco łagodniej pojmuje ambiwalencję moralną E. Erde pisząc, że profesjonalizm ma dwie strony, jasną "krzewiącą dobro” i ciemną „przysparzającą kłopotów”"109. Do ciemnej strony zalicza - oprócz ochrony profesjonalnych interesów medyków kosztem dobra pacjentów - także tłumienie indywidualności lekarzy poprzez etykietowanie odmienności jako nieprofesjonalnych.

Bliską ambiwalencji moralnej jest następna wada profesjonalizmu, mianowicie związana z jego kulturą „mentalność “my - oni'”110. Na krajowym podwórku jednym z jej przejawów było powołanie w 2010 roku rzecznika praw lekarza, które można potraktować jako odpowiedź na ustanowienie rzecznika praw pacjenta. W profesjonalizmie tradycyjnym mentalność różnicująca spełniała $w$ dużej mierze pozytywne zadanie cementowania słabej wówczas społeczności medyków. Współcześnie trudno się w niej doszukać jakichkolwiek dodatnich stron. Zwolennicy profesjonalizmu odnowionego mentalności różnicującej nie dostrzegają. Przypomnę, że według H. Swicka wartości humanistyczne są kluczowe dla pracy profesjonalisty. Zrównywanie humanizmu i profesjonalizmu ostro skrytykował Judah Goldberg ${ }^{111}$. Po pierwsze, humanizm to egalitarna i uniwersalna ideologia, podczas gdy profesjonalizm reprezentuje prowincjonalne, kulturowo zdeterminowane sposoby postępowania partykularnych grup zawodowych. Po drugie, humanizm w swej istocie jest filozofią i stanowi przedmiot racjonalnego dyskursu. Profesjonalizm natomiast jest zjawiskiem społecznym. Najważniejszy sposób inicjacji profesjonalnej nie polega na racjonalnym jego nauczaniu, lecz raczej na intensywnym procesie socjalizacji, w trakcie którego nowicjusze przyswajają tradycję swojej grupy. Dodam, że w medycynie socjalizacja jest szczególnie intensywna i polega na formowaniu "drugiej natury" lekarza odmiennej od natury laika ${ }^{112}$.

Za efektywny instrument umacniania humanizmu wśród studentów medycyny uznawana jest ceremonia białego fartucha z dwoma głównymi rytuałami - przywdziewaniem kitla lekarskiego i publicznym przepowiadaniem (najczęściej) Przysięgi Hipokratesa. Jej początki sięgają prawdopodobnie 1993 roku ${ }^{113}$. Również w Polsce na niektórych wydziałach lekarskich organizowane są podobne ceremonie ${ }^{114}$. J. Goldberg bardzo krytycznie odnosi się do tego obyczaju. Sprawia on, że locus humanizmu z ukrytej

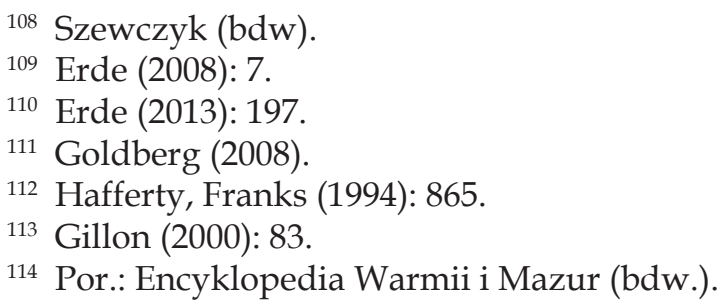


w fartuchu, podatnej na zranienie ludzkiej istoty przenoszony jest na zewnętrzny mundur-kitel będący znakiem odróżniającym przyszłego medyka od społeczeństwa. Autor wolałby fartuch-symbol elity zastąpić w ceremonii „wspólną szatą ludzkiej kruchości - szlafrokiem szpitalnym"115. W obecnej postaci ceremonia nie propaguje humanizmu, a jedynie umacnia moralność różnicującą. Co więcej, jej popularyzacja grozi „trywializacją" profesjonalizmu - redukowaniem go do zachowań etykietalnych ${ }^{116}$.

Kolejną negatywną częścią profesjonalizmu jest związana z nim „moc krzywdzenia jego członków"117. Ma ona dwa główne źródła. Pierwszym jest nadmierne akcentowanie wagi cnót samopoświęcenia i perfekcjonizmu zawodowego dla dobrego doktorzenia. Jego niepożądanym efektem jest wypalenie zawodowe i pracoholizm. W skrajnych przypadkach może prowadzić nawet do porzucenia własnej rodziny, przyjaciół, a także stanów depresyjnych i zaniku radości życia ${ }^{118}$. W świecie lekarskim narasta sprzeciw wobec uznawania samopoświęcenia i ciężkiej pracy za jedną z centralnych cech profesjonalizmu. Lawrence Smith łączy to z „różnicą pokoleniową” między lekarzami. Dzisiejsi studenci wywodzą się z „unikatowej generacji” dojrzewającej w atmosferze sceptycyzmu kulturalnego, obytej technologicznie, ceniącej czas wolny i zachowującej równowagę między pracą a życiem prywatnym. Duży wpływ na bilansowanie sfery zawodowej i prywatnej mają kobiety tłumnie napływające na studia lekarskie ${ }^{119}$. Dominującą cechą unikatowej generacji jest indywidualizm. Przypomnę, że środowiskiem starszego pokolenia medyków była kultura mieszczańska z jej etosem pracy, a medycynę uprawiali praktycznie wyłącznie mężczyźni. Natomiast Kodeks podkreślał znaczenie wspólnotowości - braterstwa profesjonalistów.

Jako ilustrację stosunku nowego pokolenia lekarzy do cnoty samopoświęcenia przywołam fragment wywiadu z Piotrem Wojcieszkiem, stażystą miejskiego szpitala: „Postaram się zostać kardiologiem i napisać doktorat. Przede wszystkim chciałbym być zadowolony z tego, co robię... Chciałbym też założyć rodzinę”. Na stwierdzenie prowadzących wywiad, iż „Doświadczeni profesorowie mówią, że lekarz powinien raczej ożenić się z medycyną”, P. Wojcieszek reaguje: „Nie. To byłoby złe. Rodzina daje oparcie. Moi rodzice są lekarzami i stworzyli szczęśliwy związek"120. To napięcie międzygeneracyjne jest już na tyle silne, że F. Hafferty mówi nawet o „bitwach pokoleniowych” między „starą szkołą" profesjonalizmu a nowym pokoleniem lekarzy ${ }^{121}$.

Drugim źródłem mocy krzywdzenia profesjonalistów przez profesjonalizm jest nadal intensywnie obecna skłonność do poniżania studentów i osób na niższych szczeblach hierarchii zawodowej ${ }^{122}$. W tym kontekście Paul Heidet i Howard Stein piszą nawet o zjawisku, które można nazwać kulturą poniżania studentów i podwładnych. Przejawia się ona między innymi w ich zastraszaniu, publicznym zawstydzaniu i upokarzaniu ${ }^{123}$.

\footnotetext{
115 Goldberg (2008): 721.

116 Kuczewski (2010): 33.

117 Ibidem: 18.

118 Zob. też: Gołota (2017).

119 Smith (2005): 439.

120 Wojcieszek (2006): 6-7.

121 Hafferty (2009): 65.

122 Szewczyk (2018): 70-72.

123 Heidet, Stein (2006): S17.
} 
Można sądzić, że skazą krzywdzenia nieco mniej obarczony jest profesjonalizm odnowiony. Refleksja nad własnymi działaniami i decyzjami jako zachowanie proponowane przez H. Swicka sprzyja momentowi spokoju i dystansu do profesjonalnej codzienności i może złagodzić negatywne oddziaływanie cnót altruizmu i samopoświęcenia. Natomiast wątpię, czy taka refleksja może zmniejszyć destrukcyjny wpływ kultury poniżania.

Krytycy profesjonalizmu zwracają uwagę na brak jego teoretycznego ufundowania $^{124}$. Z zarzutu tego należy wyłączyć prehistorię profesjonalizmu tradycyjnego. Pamiętamy z podpunktu 1.a., że J. Gregory i T. Percival inspirację dla swoich poglądów czerpali z pism F. Bacona i filozofów szkockiego oświecenia. Natomiast czas redagowania Kodeksu z 1847 roku i tworzenia podwalin pod profesjonalizm tradycyjny to "ciemne wieki etyki lekarskiej” ${ }^{25}$. Samoizolacja środowiska lekarskiego od filozofii zaowocowała brakiem refleksji profesjonalizmu nad własnym podstawami teoretycznymi. Według mnie odniesienia profesjonalizmu odnowionego do humanizmu i błędne jego zakorzenianie w tradycji sięgającej Hipokratesa (Karta) są próbą zminimalizowania omawianej wady. Szacowność tej wielowiekowej tradycji i powszechne uznanie w naszej kulturze dla humanizmu wydają się zwolennikom profesjonalizmu wystarczającym substytutem jego teoretycznych fundamentów i dobrym usprawiedliwieniem jego roszczeń.

Wykaz (poważnych) wad kończę zasygnalizowaniem skazy, jaką jest nostalgia. Przyjmując interpretację tej wady dokonaną przez B. Castellaniego i F. Hafferty'ego powiemy, że dotknięty jest nią wyłącznie profesjonalizm odnowiony łącznie z jego formą instytucjonalną. Stąd właśnie ukuta przez nich nazwa "profesjonalizm nostalgiczny”. Zdaniem przywołanych autorów, jest on próbą odbudowy poddanego idealizacji „dawnego profesjonalizmu" ufundowanego na autonomii i dominacji lekarzy, podjętą przez "klasę rządząca" medycyną. Jednocześnie wyraża on tęsknotę za nim. Klasa rządząca to - w ujęciu autorów - elita medycyny instytucjonalnej. Tworzą ją liderzy medycyny akademickiej, redaktorzy wiodących czasopism branżowych oraz funkcjonariusze rozmaitych organizacji profesjonalnych, w tym AMA ${ }^{126}$. E. Erde pisze wręcz o „naiwnej nostalgii” przenikającej całość świata medyków, a nie tylko klasę nim rządzącą ${ }^{127}$. Podobnie jak u poprzednich autorów ma ona być wyrazem tęsknoty za minionym prestiżem lekarzy, samodzielnymi praktykami i autonomią. E. Erde stwierdza, że jest to nostalgia za czasem, którego nigdy nie było. Jednakże jak sugerują analizy podpunktu 1.c. bliskie realizacji tej profesjonalnej tęsknoty były złote lata medycyny amerykańskiej. Tak interpretowany nostalgiczny aspekt profesjonalizmu odnowionego pokazuje, jak niebezpieczna dla pacjentów może być jego ciemna strona.

E. Erde daje także inne wyjaśnienie nostalgicznego wymiaru profesjonalizmu. W tym ujęciu jest on „endemiczny” ${ }^{128}$ w środowisku lekarzy i edukatorów, to znaczy, że nie pojawił się wraz z profesjonalizmem odnowionym i skażony jest nim również profesjonalizm klasyczny. Endemiczność nostalgii świadczy, że tęsknota w profesjonalizmie jest nie tyle zaburzeniem pamięci, ile pogonią za niemożliwym do zrealizowania ideałem

\footnotetext{
${ }^{124}$ McCullough (2006): 19-23.

125 Veatch (2013): 166-167.

126 Castellani, Hafferty (2006): 12.

127 Erde (2008): 6.

128 Ibidem: 20.
} 
lekarza-profesjonalisty. Profesjonalizm przeradza się w „nostalgiczny utopizm” ${ }^{129}$. Zdarzają się jednostki spełniające jego wymogi (np. zachowujące się zgodnie z podanymi przez H. Swicka opisami), lecz zawsze są to tylko jednostki. Niedoskonałość profesjonalizmu zmienia się tu według mnie w wyzwanie edukacyjne: Jak ważyć rzeczywiste możliwości i warunki dobrego doktorzenia z propagowanym przez profesjonalizm jego ideałem. Ceną niewłaściwego ważenia jest, z jednej strony, utrata zaufania społecznego do profesji, a z drugiej - rozbicie integralności profesjonalnej najbardziej moralnie wrażliwych lekarzy, wystawienie ich na samotność sumienia profesjonalnego i konflikt między tym ostatnim a sumieniem indywidualnym.

\section{4.b. Zalety profesjonalizmu tradycyjnego i odnowionego}

Pierwszy bardzo ważny pozytyw profesjonalizmu, w szczególności tradycyjnego, widzę w silnym łączeniu dążenia do perfekcji klinicznej (oraz badawczej) z osiąganiem doskonałości moralnej. Podkreślanie ich jedności może zapobiegać zbyt daleko idącemu oddzielaniu w decyzjach medycznych składnika sensu stricto medycznego (faktualnego) od komponentu moralnego. Odłączenie tego drugiego otwiera drogę do zawłaszczenia medycyny przez zewnętrzne wobec niej siły między innymi wolnego rynku, prawa czy bioetyki. Jego konsekwencją jest odmoralnienie (demoralization) $)^{130}$ medycyny prowadzące do zamiany profesjonalisty w technika, a także do przekształcenia zasady szacunku dla autonomii z prawa pacjenta $\mathrm{w}$ jej obsesję wspomnianą już w punkcie 2.a. i do groźby całkowitego przerzucenia na barki chorego odpowiedzialności decyzyjnej za proces terapeutyczny. Składnik moralny tworzy się w historii profesjonalizmu. Pielęgnowanie tradycji moralnej przez profesjonalizm podnosi wagę tej części decyzji medycznych i wraz ze wspólnotowością jako braterstwem może zapobiegać moralnemu osamotnieniu lekarzy, co uznaję za kolejną zaletę profesjonalizmu.

Przywiązanie lekarzy do własnej tradycji profesjonalnej jest pozytywem także i dlatego, że jej przesłanie stanowi wskazówkę naprawy zmian we współczesnym etosie, niekorzystnych dla nich i dla pacjentów. Zgodnie ze wskazówką tą korekta winna płynąć z samego środowiska. Jak uczą początki jego kształtowania się, profesjonalizm nie "spłynął spod pióra Hipokratesa"131, lecz stanowi wytwór zbiorowych klinicznych i moralnych osądów, decyzji i zachowań lekarzy i dzięki nim nadal istnieje. Podmioty zewnętrzne nie stworzyły profesji. Nie mogą jej także zniszczyć ani okaleczyć. To sami lekarze są w pełni odpowiedzialni za niekorzystne zmiany profesji, stwierdza kategorycznie L. McCullough ${ }^{132}$. Ich naprawa jest zadaniem profesjonalistów, wymagającym odpowiednich przeobrażeń w osądach, decyzjach i zachowaniach medyków. W zbiorowej umiejętności dokonywania takich modyfikacji wyraża się w mojej opinii istota autonomii profesjonalnej lekarzy.

Kolejny pozytyw profesjonalizmu widzę w akcentowaniu przez niego wspólnotowości środowiska medyków, szczególnie wyraźnym w profesjonalizmie tradycyjnym.

129 Erde (2013): 200.

130 Montgomery (2006), por. też: Szewczyk (2016): 51 i n.

131 McCullough (2006): 24.

132 Ibidem. 
Wspólnotowość rozumiana nie w sposób różnicujący, lecz jako braterstwo lekarzy może pomóc w edukacji formacyjnej adeptów medycyny, a lekarzom w ich codziennej pracy. Łagodzi także niekorzystne wpływy kursu pozaformalnego z jego kulturą poniżania.

Jednakże najistotniejsza według mnie zaleta profesjonalizmu wynika paradoksalnie z jego ambiwalencji. Aby z niej korzystać nie wolno zapominać o ciemnej stronie tej ideologii, jak się to często zdarza jego zwolennikom i wychowawcom ${ }^{133}$. Jej obecność powoduje napięcie między, mówiąc skrótowo, dobrem przysparzanym przez profesjonalizm i złem, do jakiego może doprowadzić. Profesjonalizm lekarza przejawia się w jego czujności moralnej umożliwiającej mu dostrzeżenie tego napięcia oraz w wysiłku umieszczania profesjonalnych cnót (wartości, zachowań) w centrum „lekarskiego życia”"134. Wysiłek ten jest $\mathrm{w}$ istocie szukaniem Arystotelesowskiego złotego środka między profesjonalnymi skrajnościami w danej sytuacji wyboru postępowania. Utrata czujności grozi niebezpieczeństwem ześlizgnięcia się profesjonalizmu w schemat znany ze złotych lat medycyny amerykańskiej łącznie z profesjonalnym osamotnieniem moralnym lekarzy skazanych na rozterki sumienia indywidualnego. Jak sugeruje cytowana w podpunkcie 1.c. rada J. Bogusza, niebezpieczeństwo to nie jest obce także polskiemu profesjonalizmowi.

Sytuacji, w których wybór właściwego moralnie postępowania zależy od ważenia przeciwstawnych zachowań jest wiele w medycynie. Przywoływanie przykładów rozpocznę od cnoty samopoświęcenia. Jest to - jak pokazywałem - jedna z najstarszych i zarazem fundamentalnych cnót profesjonalizmu. Od profesjonalisty wymaga się "znacznego samopoświęcenia"135. Jak znaczne ma ono być? Jak wypośrodkować między całkowitym oddaniem się pracy opisywanym przez J. Bogusza, a hołdowaniem wartościom rodzinnym ilustrowanym wypowiedzią P. Wojcieszka? Dla odnowionego profesjonalizmu poszukiwanie „etycznie uzasadnionych” granic cnoty samopoświęcenia staje się "tematem centralnym profesjonalnej etyki medycznej"136. Inną postacią tego dylematu jest napięcie między indywidualizmem dzisiejszego pokolenia medyków a wspólnotowością ważną dla profesjonalizmu.

Cenną profesjonalną umiejętnością jest odnajdywanie złotego środka między wymogami medycyny wiarygodnej (Evidence-Based-Medicie) a sygnalizowanym przez H. Swicka realiami pracy lekarza w sytuacji wysokiej złożoności i niepewności. Niezwykle ważna dla profesjonalisty jest zdolność zachowania właściwej miary między dążeniem do ideału, jakim dla profesjonalizmu tradycyjnego i odnowionego jest zachowanie życia i zdrowia pacjentów, a unikaniem leczenia daremnego medycznie. Dla współczesnego lekarza pracującego w sytuacji konfliktu wielu interesów szczególnie istotna jest zdolność ich ważenia w sposób nienaruszający umowy-przymierza z pacjentem. Na koniec wspomnę o profesjonalnej zdolności opierania się naciskom przemysłu farmaceutycznego przy jednoczesnym umiejętnym korzystaniu z nowości rzeczywiście przydatnych w lecznictwie. Sztuka ważenia jest niezbędna również dla (od)budowy zaufania między profesją a społeczeństwem, na którą słusznie kładzie tak wielki nacisk profesjonalizm odnowiony.

133 Erde (2008): 7.

134 Inui (2003): 21.

135 McCullough (2006): 23.

136 Ibidem. 
Profesjonalizm odnowiony jest jeszcze w dużej mierze ideałem profesjonalizmu lekarskiego, do którego zdaniem zwolenników należy dążyć w edukacji i praktyce klinicznej. Próby jego budowania pobudziły do refleksji nad okrzepłym już profesjonalizmem klasycznym. Ułatwiły tym samym dostrzeżenie zasygnalizowanych wyżej wad profesjonalizmu w ogóle. I to jest ostatnia z zalet profesjonalizmu odnowionego, na którą chcę zwrócić uwagę.

\section{Przydatność profesjonalizmu w edukacji moralnej studentów i młodych lekarzy}

Z dotychczasowych rozważań wynika, że profesjonalizmu nie wolno utożsamiać ani z nową (akademicką) etyką lekarską, ani z bioetyką ${ }^{137}$. Nie powinien on także ich zawłaszczać. Dla każdej z tych dziedzin aktywności można poszukiwać miejsca, z którego będzie moralnie kształtować lekarzy i służyć medycynie jako przedsięwzięciu moralnemu.

Transformacja studentów (laików) w lekarzy jest intensywnym procesem socjalizacji zaczynającym się już od pierwszych lat studiów i trwa aż po rezydenturę bądź staż. Stawanie się lekarzem obejmuje nie tylko nabywanie profesjonalnych umiejętności i wiedzy. Jest także przemianą ich charakteru, kształtowaniem wspomnianej w poprzednim punkcie drugiej natury. $W$ tym procesie nauczanie profesjonalizmu może odegrać pozytywną rolę w sposób trojaki. Po pierwsze, profesjonalizm odnowiony jako "aplikacja cnoty” może uzupełnić świecką etykę lekarską. Jest ona mało zainteresowana aretologicznym wymiarem edukacji moralnej. Ta obojętność może przyczyniać się do jej nieskuteczności w zapobieganiu rosnącemu w trakcie studiów cynizmowi słuchaczy ${ }^{138}$. Nie należy jednak w edukacyjnym aplikowaniu cnót upatrywać cudownej metody kształtowania moralnych postaw medyków. Oczekiwanie, że włączenie profesjonalnej etyki cnót do obowiązkowych kursów odwróci wyraźną wśród studentów starszych lat i młodych lekarzy niechęć do altruizmu i samopoświęcenia może być, jak zauważa E. Erde, "naiwnie optymistyczne" ${ }^{\prime 139}$.

Ważne powody owego sceptycyzmu sygnalizuje Robert Veatch ${ }^{140}$. Jego zdaniem etyka cnót nie jest w stanie sformułować wykazu cech charakteru, które powinny być nauczane w edukacji profesjonalnej, nie ma w niej bowiem „wspólnej moralności”, na której taki katalog mógłby się opierać. Według przywołanego autora jej określenie jest niemożliwe przede wszystkim z powodu dużego zróżnicowania kulturowego pacjentów. Dodałbym, że na niemożność formułowania wspólnej moralności wpływa także wspomniana w poprzednim punkcie miałkość teoretycznego ugruntowania profesjonalizmu. Kolejnym powodem sceptycyzmu edukacyjnego jest brak dowodów na pozytywną korelację między charakterem lekarza a jego postępowaniem. Nawet w świetle takich dowodów - gdyby się znalazły - cnoty pozostawałyby nadal jedynie środkami do motywowania moralnie właściwych zachowan - nadal nie miałyby wartości autotelicznej. Są też przyczyny bardziej praktycznej natury. Tym, co rzeczywiście interesuje pacjentów w klinicznych relacjach - pisze R. Veatch - jest to, czy zachowanie lekarzy jest

137 Por. też: Wear, Kuczewski (2004): 4; Dunn (2016).

138 Erde (2013): 196.

${ }^{139}$ Erde (2008): 7.

${ }^{140}$ Veatch (2006): 32-42. 
właściwe, a nie to, czy jest ono rezultatem prawego charakteru. Profesjonaliści są skłonni podzielać ten pogląd. Niewykluczone, że jego zwolennikami są redaktorzy Karty lekarza. Dokument ten w ogóle nie wspomina o cnotach i ich znaczeniu dla profesjonalizmu. Także wpływowy artykuł H. Swicka milczy na ten temat koncentrując się na katalogu profesjonalnych zachowan.

Po drugie, edukacyjną funkcję formowania charakteru profesjonalizm może wypełniać poprzez ukazywanie studentom i młodym lekarzom nie tylko jasnych, ale i przede wszystkim - ciemnych swoich stron. Wychowanie profesjonalne pełni wówczas zadania korekcyjne wobec kursów pozaformalnych. Te bowiem częstokroć wdrażają wychowanków w ciemną stronę profesjonalizmu zazwyczaj w sposób nieświadomy również i dla samych wychowawców. Z tej przyczyny edukacja profesjonalna uwzględniająca obie strony profesjonalizmu może pozytywnie wpłynąć także na wychowanie moralne zespołów nauczających i praktykujących w klinikach uniwersyteckich często niedoceniających destrukcyjnych mocy jego ciemnej strony. Oddziaływanie formacyjne ukazujące obie strony profesjonalizmu z wymienionych wyżej powodów jest bardziej niż edukacja aretologiczna efektywne w pożądanej transformacji moralnej laików w profesjonalistów. Po trzecie, pozytywną edukacyjną rolę profesjonalizmu widzę w wyrabianiu fundamentalnej dla dobrego doktorzenia umiejętności właściwego ważenia jasnych i ciemnych stron, znajdowania Arystotelesowskiego środka między nimi. Jest to bowiem w mojej opinii jedna z najbardziej kluczowych zdolności, które powinny cechować profesjonalistę.

Za kształtowanie profesjonalnego charakteru studentów i młodych lekarzy odpowiedzialni są przede wszystkim lekarze nauczający własnym przykładem i będący tzw. wzorcami (models) osobowymi - ucieleśniającymi cnoty, wartości i zachowania profesjonalisty. Kłopot w tym, że lekarze ci, jak cytowany J. Bogusz, sami są uformowani przez tradycję moralną i kulturę profesji, nierzadko także z jej negatywną, czyniącą zło stroną. Jak wspominałem, częstokroć nie dostrzegają bądź nie chcą dostrzegać tego negatywnego dziedzictwa i ostrzegać przed nim wychowanków ${ }^{141}$. Z tych to powodów edukatorzy rolę przewodnika i nauczyciela profesjonalizmu widzą w mentorze ${ }^{142}$. Ze studentami i młodszymi lekarzami łączy go relacja mistrz - uczeń wzorowana na właściwym dawniejszej medycynie modelu terminowania osadzonym w klinice. W odróżnieniu od wzorca osobowego, mentor świadomie i intencjonalnie kieruje "terminowaniem" w profesji adeptów medycyny i młodszych kolegów. Osoba spełniająca w kadrze uniwersyteckiej rolę mentora musi wskazywać na ciemne i jasne strony profesjonalizmu i dążyć do kształtowania profesjonalnego wychowanków umożliwiającego im ważenie tych pozytywów i negatywów.

Ósme zachowanie profesjonalisty podane przez H. Swicka (umiejętność pracy w warunkach dużej złożoności i niepewności) daje interesujące wskazówki edukacyjne. Studenci w latach przedklinicznych na zajęciach z biochemii, fizjologii czy immunologii otrzymują błędną informację, że w naukach przyrodniczych nie ma niepewności czy niejednoznaczności wniosków. Wzbudza to w nich skłonności do postrzegania siebie

\footnotetext{
${ }_{141}$ Zob. też: Erde (1997): 31-45.

142 Rhodes, Smith (2006): 111.
} 
jako „ignorantów technicznych" i „moralnych”"143. Postawa taka szczególnie mocno powiązana z profesjonalizmem tradycyjnym sprzyja wspomnianej w poprzednim punkcie kulturze napiętnowania. Wątpliwości są w efekcie tej postawy traktowane jak przejaw zasługującej na naganę ignorancji profesjonalnej. Stawia ona tym samym pod znakiem zapytania zadania formacyjne profesjonalizmu odnowionego. Nie możemy bowiem - jak słusznie stwierdza Mark Kuczewski - „oczekiwać, że w ramach systemów edukacyjnych, w których studenci traktowani są w sposób bezduszny a czasem wręcz agresywny, wykształcimy współczujących i prawych lekarzy"144. Utrwalanie omawianej skłonności owocuje kolejną ujemną konsekwencją, mianowicie przekonaniem lekarzy, że niepewności i złożoności należy unikać, że każdy problem ma zawsze jedno właściwe rozwiązanie. Powoduje to ucieczkę w dogmatyzm moralny pozwalający na (pozorne) uwalnianie się od niepewności i złożoności decyzyjnej. Dzięki dogmatycznemu trzymaniu się utartych i stosowanych przez wyższych w hierarchii lekarzy sposobów klinicznego postępowania, pozwala im również na osłabianie zagrażającego ze strony starszych kolegów niebezpieczeństwa publicznego zawstydzania i upokarzania.

Przygotowanie studentów i młodych lekarzy do pracy w warunkach złożoności i niepewności decyzyjnej zminimalizuje (mam nadzieję) zasygnalizowane konsekwencje silnie ujemnie wpływające na kulturę profesjonalną, etykę praktykowania medycyny i komfort psychiczny lekarzy. Mentor już na etapie przedklinicznym powinien wyjaśniać studentom, że również w naukach zwanych ścisłymi jest miejsce na niepewność i odmienność poglądów. Natomiast słuchaczom starszych lat należy uświadamiać, że niepewność i złożoność decyzyjna jest nieodłączna od praktyki medycznej i uczyć ich sposobów radzenia sobie z przyszłymi i aktualnymi sytuacjami niepewności. Praktyczne zetknięcie się ze złożonością i niepewnością jest szczególnie dotkliwe dla początkujących lekarzy. Uczelnie medyczne powinny wdrażać programy edukacyjne przygotowujące ich do pracy w takich warunkach oraz - co bardzo ważne - włączać w nie osłabiające kulturę napiętnowania narzędzia pomocy w trudnościach i niepowodzeniach wiążących się z niepewnością i wysoką złożonością decyzyjną. Przykład takiego programu wziąłem z kursu dla rezydentów Szpitala Uniwersyteckiego w Rochester ${ }^{145}$.

Miejscem jego realizacji jest "grupa wsparcia” działająca przez cały okres rezydentury. Na pierwszym spotkaniu (przy lunchu) moderowanym przez odpowiednio przygotowanych nauczycieli akademickich (mentorów), lekarze mają sposobność dyskusji na temat ich osobistego systemu wartości, filozofii, doświadczeń z ich dotychczasowej pracy, dzielenia się radościami, dążeniami, planami małżeńskimi i rozwojem kariery. Rezydenci starszych lat opowiadają na spotkaniach o swoich profesjonalnych niepowodzeniach, analizują je i związane z nimi doznania, ucząc się szczerości i pokory. Wartości te sprawiają, że rezydenci mówiąc o porażkach budzą empatię i wspierają się w przepracowywaniu tych niepowodzeń. Buduje się silna więź między członkami grupy wsparcia. Kodeks z 1847 braterstwo opierał na arystokratyzmie moralnym i wyniosłości,

\footnotetext{
${ }^{143}$ Hafferty, Franks (1994): 865.

144 "We cannot expect to develop compassionate and virtuous physicians in educational systems that are insensitive and at times abusive toward their students". Kuczewski (2010): 35-36.

${ }^{145}$ Markakis, Beckman, Suchman, Frankel (2000): 145-146.
} 
bliskich ciemnej stronie profesjonalizmu. Omawiany kurs podstawą wspólnoty profesjonalnej czyni pokorę, uczciwość, empatię i dodałbym - także wspólną i lekarzom, i pacjentom podatność na zranienie. Inaczej mówiąc, fundamentem braterstwa jest jasna strona profesjonalizmu. Wymienione wartości przekazywane są następnym generacjom rezydentów i można założyć, że przyczyniają się do osłabienia ciemnej strony profesjonalizmu - przede wszystkim - wspomnianej mocy krzywdzenia jego członków.

Z przedstawionego opisu przydatności edukacyjnej profesjonalizmu wynika, że jestem w tej kwestii bardzo umiarkowanym - nie naiwnym - optymistą. W polskich warunkach optymizm ten pomniejsza jeszcze, i to znacznie, wątpliwość dotycząca dostępności odpowiednio wykształconych mentorów mogących skutecznie w procesie wychowawczym przeciwstawiać się ciemnej stronie profesjonalizmu przekazywanej przez kursy pozaformalne.

\section{Bibliografia}

ABIM Foundation, ACP-ASIM Foundation, European Federation of Internal Medicine (2002), Medical Professionalism in the New Millennium: A Physician Charter, "Annals of Internal Medicine" 136 (3): 243-246.

American Medical Association (1847), Code of Medical Ethics, Chicago, URL = https:/ / www. ama-assn.org/sites/default/files/media-browser/public/ethics/1847code_0.pdf [dostęp 16.06.2018].

American Medical Association (1999), Principles of Medical Ethics, [w:] The American Medical Ethics Revolution, R.B. Baker, A. Caplan, L. Emanuel, S. Latham (red.), Johns Hopkins University Press, Baltimore 1999: 346-354.

Baker R.B. (1999), The American Medical Ethics Revolution, [w:] The American Medical Ethics Revolution, R.B. Baker, A. Caplan, L. Emanuel, S. Latham (red.), Johns Hopkins University Press, Baltimore: 17-51.

Baker R.B. (2002), Bioethics and History, "Journal of Medicine and Philosophy" 27 (4): 447-474.

Baker R.B. (2013), Before Bioethics: A History of American Medical Ethics from the Colonial Period to the Bioethics Revolution, Oxford University Press, Oxford.

Baker R.B., Caplan A., Emanuel L., Latham S. (1999), Introduction, [w:] The American Medical Ethics Revolution, R.B. Baker, A. Caplan, L. Emanuel, S. Latham (red.), Johns Hopkins University Press, Baltimore: XXXII-XXXIX.

Beaton G. (2010), What Professionalism Is Still Relevant?, „Legal Studies Research Paper” 445, Melbourne Law School: 1-23.

Blendon R.J., Benson J.M., Hero J.O. (2014), Public Trust in Physicians - U.S. Medicine in International Perspective, „New England Journal of Medicine” 371 (17): 1570-1572, URL =

http:/ / www.nejm.org/doi/pdf/10.1056/NEJMp1407373 [dostęp 25.06.2018].

Bogusz J. (1984), Lekarz i jego chorzy, PZWL, Warszawa.

Bogusz J. (1985), Zasady deontologiczne zwiazane z postępami wiedzy lekarskiej, [w:] Etyka i deontologia lekarska, T. Kielanowski (red.), PZWL, Warszawa: 77-116.

Boyd K.M. (2005), Medical Ethics: Principles, Persons, and Perspectives: From Controversy to Conversation, "Journal of Medical Ethics" 31 (8): 481-486.

Brecher B. (2004), Against Professional Ethics, „Philosophy of Management” 4 (2): 3-8.

Brennan T.A. (2002), Physicians' Professional Responsibility to Improve the Quality of Care, "Academic Medicine" 77 (10): 973-980. 
Brody H., Doukas D. (2014), Professionalism: A Framework to Guide Medical Education, „Medical Education" 48 (10): 980-987.

Callahan D. (1984), Autonomy: A Moral Good Not a Moral Obsession, „Hastings Center Report” 14 (5): 40-42.

Capron M.A. (1999), Professionalism and Professional Ethics, [w:] The American Medical Ethics Revolution, R.B. Baker, A. Caplan, L. Emanuel, S. Latham (red.), Johns Hopkins University Press, Baltimore: 180-191.

Cassell E.J. (2013), The Beginnings of Bioethics, [w:] The Development of Bioethics in the United States, J.R. Garrett, F. Jotterand, D.Ch. Ralston (red.), Springer, Dordrecht: 16-25.

Castellani B., Hafferty F.W. (2006), The Complexities of Medical Professionalism: A Preliminary Investigation, [w:] Professionalism in Medicine: Critical Perspectives, D. Wear, J.M. Aultman (red.), Springer, New York: 3-24.

Clements C.D., Sider R.C. (1983), Medical Ethics' Assault Upon Medical Values, „Journal of American Medical Association" 250 (15): 2011-2015.

Coulehan J. (2005), Today's Professionalism: Engaging the Mind but Not the Heart, "Academic Medicine" 80 (10): 892-898.

De M. (2004), Towards Defining Paternalism in Medicine, "AMA Journal of Ethics" 6 (2), URL = http://journalofethics.ama-assn.org/2004/02/fred1-0402.html [dostęp 20.06.2019].

Dunn M. (2016), On the Relationship Between Medical Ethics and Medical Professionalism, ,Journal of Medical Ethics" 42 (10): 625-626.

Dzur A.W. (2008), Democratic Professionalism. Citizen Participation and the Reconstruction of Professional Ethics, Identity, and Practice, Pennsylvania State University Press, University Park.

Encyklopedia Warmii i Mazur (bdw.), Ceremonia biatego fartucha, URL = http:/ / encyklopedia. warmia.mazury.pl/index.php/Ceremonia_Bia\%C5\%82ego_Fartucha\#Bibliografia [dostęp 26.06.2018].

Erde E.L. (1997), The Inadequacy of Role Models For Educating Medical Students in Ethics With Some Reflections on Virtue Theory, "Theoretical Medicine” 18 (1-2): 31-45.

Erde E.L. (2008), Professionalism's Facets: Ambiguity, Ambivalence, and Nostalgia, „Journal Medicine and Philosophy" 33 (1): 6-26.

Erde E.L. (2013), Professionalism vs. Medical Ethics in the Current Era: A Battle of Giants, [w:] The Development of Bioethics in the United States, J.R. Garrett, F. Jotterand, D.Ch. Ralston (red.), Springer, Dordrecht: 179-206.

Freidson E. (1999), Professionalism and Institutional Ethics, [w:] The American Medical Ethics Revolution, R.B. Baker, A. Caplan, L. Emanuel, S. Latham (red.), Johns Hopkins University Press, Baltimore: 124-143.

Gillon R. (2000), White Coat Ceremonies for New Medical Students, "Journal of Medical Ethics" 26 (2): 83-84.

Giubilini A., Milnes S., Savulescu J. (2016), The Medical Ethics Curriculum in Medical Schools: Present and Future, "Journal of Clinical Ethics” 27 (2): 129-145.

Goldberg J.L. (2008), Humanism or Professionalism? The White Coat Ceremony and Medical Education, "Academic Medicine" 83 (8): 715-722.

Gołota M. (2017), Lekarze nie chodza do psychiatry, a powinni, Gazeta.pl, URL = http:/ / weekend.gazeta.pl/weekend/1,152121,21961063,polscy-lekarze-nie-chodza-do-psychiatry-a-powinni-zdarza.html [dostęp 27.06.2018].

Hafferty F.W. (2009), Professionalism and the Socialization of Medical Students, [w:] Teaching Medical Professionalism, R.L. Cruess, S.R. Cruess, Y. Steinert (red.), Cambridge University Press, Cambridge: 53-71. 
Hafferty F.W., Franks R. (1994), The Hidden Curriculum, Ethics Teaching, and the Structure of Medical Education, „Academic Medicine” 69 (11): 861-871.

Hafferty F.W., Levinson D. (2008), Moving Beyond Nostalgia and Motives Towards a Complexity Science View of Medical Professionalism, „Perspectives in Biology and Medicine” 51 (4): 599-615.

Haidet P., Stein H.F. (2006), The Role of the Student-Teacher Relationship in the Formation of Physicians. The Hidden Curriculum as Process, „Journal of General Internal Medicine” 21 (Suppl. 1): S16-S20.

Inui T.S. (2003), A Flag in the Wind: Educating for Professionalism in Medicine, Association of American Medical Colleges, Washington.

Janczukowicz J. (red.) (2014), Profesjonalizm lekarski, Medical Tribune Polska, Warszawa.

Kaldjian F.Ch. (2014), Practicing Medicine and Ethics. Integrating Wisdom, Conscience, and Goals of Care, Cambridge University Press, New York.

Karta lekarza (2013), tłum. P. Gajewski, A. Juda, J. Mrukowicz, W. Strojny, „Medycyna Praktyczna", URL = https://www.mp.pl/etyka/dokumenty/86822,karta-lekarza [dostęp 20.06.2018].

Kenny N. Shelton W. (red.) (2006), Lost Virtue: Professional Character Development in Medical Education, Elsevier Ltd., Oxford.

Kowalska K., Kalbarczyk W.P. (2013), Koordynowana opieka zdrowotna. Doświadczenia międzynarodowe, propozycje dla Polski, Program EY „Sprawne Państwo”, Warszawa.

Kuczewski M.G. (2010), Teaching Biomedical Ethics As Professionalism, „Diametros” 25: 10-37.

Lindemann Nelson H., Lindemann Nelson J. (1995), The Patient in the Family. An Ethics of Medicine and Families, Rutledge, New York.

Łuków P. (2017), Non-adjectival Bioethics, „Ethics, Medicine and Public Health” 3 (4): 401-409.

Łuków P., Pasierski T. (2014), Etyka medyczna z elementami filozofii, PZWL, Warszawa.

Markakis K.M., Beckman H.B., Suchman A.L., Frankel R.M. (2000), The Path to Professionalism: Cultivating Humanistic Values and Attitudes in Residency Training, "Academic Medicine" 75 (2): 141-150.

McCullough L.B. (1998), John Gregory and the Invention of Professional Medical Ethics and The Profession of Medicine, Kluwer Academic Publishers, Dordrecht.

McCullough L.B. (2006), The Ethical Concept of Medicine: Its Origins in Modern Medical Ethics and Implication for Physicians, [w:] Lost Virtue: Professional Character Development in Medical Education, N. Kenny, W.N. Shelton (red.), Elsevier Ltd., Oxford: 17-28.

Michałowska M., Turek J. (2010), Pomoc i czyny obowiazkowe i ponadobowiazkowe w praktyce lekarskiej i bioetyce, „Etyka” 43: 125-142.

Montgomery J. (2006), Law and the Demoralization of Medicine, „Legal Studies” 26 (2): 185-210.

Montgomery J. (2016), Bioethics as Governance Practice, „Health Care Analysis” 24 (1): 3-23.

Olejniczak M. (2015), Jakiej sprawiedliwości wolno oczekiwać od lekarza?, „Diametros” 44: 78-88.

Pasierski T. (2009), Lekarz - zawód czy profesja, „Medycyna po Dyplomie” 18 (4): 133-135.

Rhodes R., Smith L.G. (2006), Molding Professional Character, [w:] Lost Virtue: Professional Character Development in Medical Education, N. Kenny, W.N. Shelton (red.), Elsevier Ltd., Oxford: 99-114.

Smith L.G. (2005), Medical Professionalism and the Generation Gap, „The American Journal of Medicine" 118 (4): 439-442.

Swick H.M. (2000), Toward a Normative Definition of Medical Professionalism, „Academic Medicine" 75 (6): 612-616. 
Szewczyk K. (1996), Lęk, nicość i respirator. Wzorce śmierci w nowożytnej cywilizacji Zachodu, [w:] Umierać bez lęku. Wstęp do bioetyki kulturowej, M. Gałuszka, K. Szewczyk (red.), Wydawnictwo Naukowe PWN, Warszawa: 14-62.

Szewczyk K. (2009), Bioetyka. Medycyna na granicach życia, Wydawnictwo Naukowe PWN, Warszawa.

Szewczyk K. (2013), Status metodologiczny bioetyki (w demokratycznym społeczeństwie prawnym) i uniwersalność norm moralnych, [w:] Etyka w medycynie wczoraj i dziś, K. Basińska, J. Halasz (red.), Impuls, Kraków: 237-260.

Szewczyk K. (2016), Odpowiedzialność moralna lekarzy i bioetyka, [w:] Etyka w medycynie. Między teoria a praktyka, A. Paprocka-Lipińska, R. Budziński (red.), Gdański Uniwersytet Medyczny, Gdańsk: 24-62.

Szewczyk K. (2018), Kurs pozaformalny w edukacji studentów medycyny i młodych lekarzy, „Diametros" 57: 61-87.

Szewczyk K. (bdw), Kazus Zofii Szychowskiej - opis, Interdyscyplinarne Centrum Etyki UJ, URL

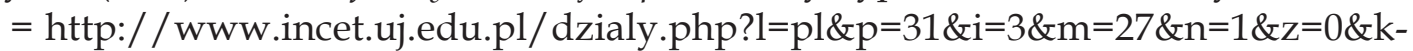
$\mathrm{k}=486 \& \mathrm{k}=103$ [dostęp 26.06.2018].

Tauber A.I. (2005), Patient Autonomy and the Ethics of Responsibility, MIT Press, Cambridge. Thomas L.-V. (1991), Trup. Od biologii do antropologii, Wydawnictwo Łódzkie, Łódź.

Tulczyński A. (1975), Polskie lekarskie kodeksy deontologiczne, PZWL, Warszawa.

Uniwersytet Medyczny w Białymstoku (2017), Profesjonalizm w medycynie, URL = https:/ / www.umb.edu.pl/pdf.php?h=/s,12782/Sylabus\&1529227616397.

Uniwersytet Warmińsko-Mazurski (2017), Elementy profesjonalizmu, URL =

https:// usosweb.uwm.edu.pl/kontroler.php?_action=katalog2/przedmioty/pokazPrzedmiot\&kod=2548SJ-ELOP.

Veatch R.B. (2006), How Philosophy of Medicine Has Changed Medical Ethics, „Journal of Medicine and Philosophy" 31 (6): 585-600.

Veatch R.B. (2006), Character Formation In Professional Education: A Word of Caution, [w:] Lost Virtue: Professional Character Development in Medical Education, N. Kenny, W.N. Shelton (red.), Elsevier Ltd., Oxford: 29-46.

Veatch R.B. (2013), The Development of Bioethics: Bringing Physician Ethics into the Moral Consensus, [w:] The Development of Bioethics in the United States, J.R. Garrett, F. Jotterand, D.Ch. Ralston (red.), Springer, Dordrecht: 163-177.

Wear D., Kuczewski M.G. (2004), The Professionalism Movement: Can We Pause?, „The American Journal of Bioethics" 4 (2): 1-10.

Włodarczyk C., Badora-Musiał K. (2017), Trwałość niektórych wyobrażeń. Niespetnione obietnice profesjonalizmu, „Problemy Polityki Społecznej. Studia i Dyskusje” 36 (1): 43-62.

Wojcieszek P. (2006), Czasem myślę o gabinecie na plaży, [w:] K. Bochenek, D. Kortko, Dobry zawód (rozmowy z lekarzami), Znak, Kraków: 5-11. 